Francisco Carvalheira Neto 

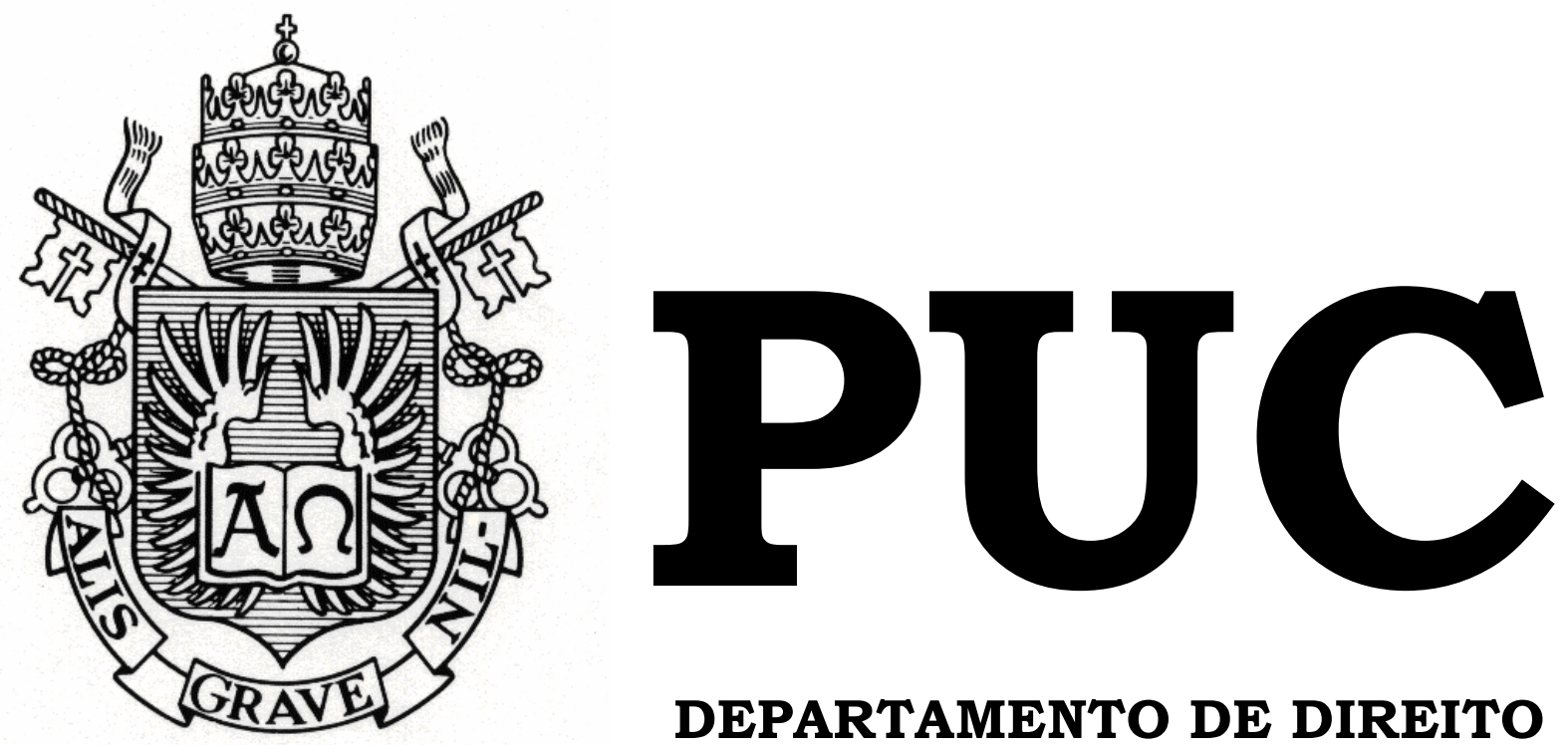

DEPARTAMENTO DE DIREITO

\title{
CAPACIDADE CONTRIBUTIVA E PROGRESSIVIDADE: UM ESTUDO SOBRE $O$ SISTEMA TRIBUTÁRIO NO BRASIL
}

\author{
por
}

FRANCISCO CARVALHEIRA NETO

ORIENTADOR: Prof. Francisco Guimaraens

2009.2

PONTIFÍCIA UNIVERSIDADE CATÓLICA DO RIO DE JANEIRO

RUA MARQUÊS DE SÃO VICENTE, 225 - CEP 22453-900

RIO DE JANEIRO - BRASIL 


\section{Capacidade contributiva e Progressividade: um estudo sobre o sistema tributário no Brasil}

por

FRANCISCO CARVALHEIRA NETO

Monografia apresentada ao

Departamento de Direito da

Pontificia Universidade Católica

do Rio de Janeiro (PUC-Rio) para

a obtenção do Título de Bacharel em Direito.

Orientador:

Francisco

Guimaraens 


\section{Resumo}

A presente monografia trata do princípio da capacidade contributiva e de seu refinamento, o postulado da progressividade; ambos sob a influência determinante do princípio da igualdade em seu aspecto material. Aquele princípio basilar à tributação é descrito pela doutrina como pressuposto e critério de graduação da tributação e como limite ao poder de tributar. São explicitados igualmente seus subprincípios e trajetória constitucional, com breve digressão sobre o debate em torno do direito ao mínimo existencial, pertinente à imunidade tributária da subsistência do indivíduo. Por sua vez, é abordada a progressividade, especialmente destacada como o subprincípio que melhor concretiza a capacidade contributiva, descrevendo-se sua adequação à diretriz constitucional de redução da desigualdade sócio-econômica; a crítica e a defesa da progressividade, assim, são também expostas, concluindo-se pela sua legitimidade e constitucionalidade.

Empreende-se, em seguida, um estudo do sistema tributário no Brasil, indagando sobre as causas que concorrem para sua regressividade geral; essa análise se faz considerando as implicações previamente explicitadas, para a formulação da política tributária, decorrentes do conteúdo do princípio da capacidade contributiva. Conclui-se, por fim, que o sistema tributário do país viola o princípio da capacidade contributiva, e deve-se conformar, para respeitá-lo, a uma estrutura progressiva de tributação. 


\section{Palavras-chave}

Princípios da capacidade contributiva e da progressividade. Princípio da igualdade em seu aspecto material. Capacidade econômica do contribuinte. Regressividade do sistema tributário no Brasil. Política tributária. Tributos indiretos. Distributivismo e desigualdade econômica. 


\section{Sumário}

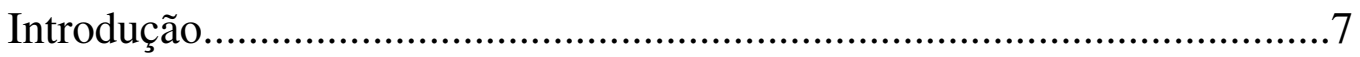

1. O princípio da capacidade contributiva...............................................12

1.1. A capacidade econômica do indivíduo como pressuposto e como critério de graduação do ônus tributário.... ........................................13

1.2. A capacidade econômica tributável: limites ao poder de tributar e direito ao "mínimo existencial" 15

1.3. A Constituição de 1988: maximizando o direito ao "mínimo"

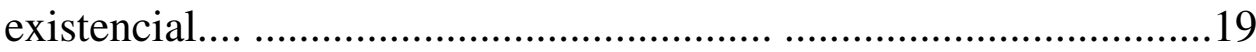

1.4. Decorrências do princípio da capacidade contributiva: progressividade, proporcionalidade, seletividade e personalização....

1.5. A trajetória constitucional do princípio da capacidade

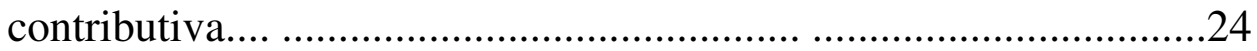

2. Refinando o princípio da capacidade contributiva: o postulado da

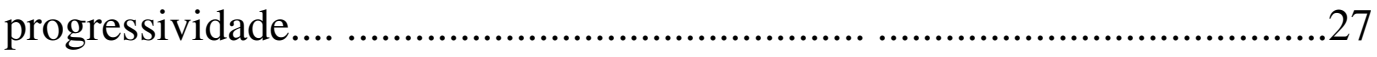

3. Um estudo do sistema tributário no Brasil: capacidade contributiva e progressividade...

3.1. Implicações do princípio da capacidade contributiva para a

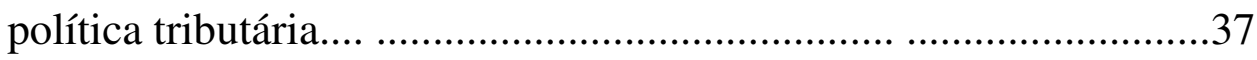

3.2. Estudo do sistema tributário do Brasil.......................................42

3.2.1.Grande participação dos tributos sobre produtos na

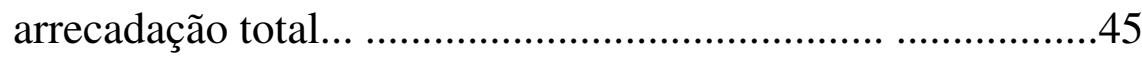

3.2.2. Reduzida participação dos tributos sobre a renda, propriedade ou capital na arrecadação total............................48

3.2.3. Estrutura dos tributos sobre renda, a propriedade e o capital........................................................................50

3.2.3.1. Imposto Predial Territorial Urbano..................50 
3.2.3.2. Imposto de Transmissão de Bens Móveis e Imóveis por Causa Mortis ou Doação............................54

3.2.3.3. Imposto Territorial Rural. .................................55

3.2.3.4. Imposto de Renda..........................................55

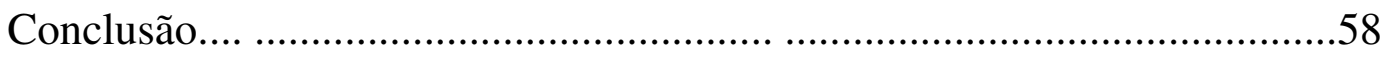

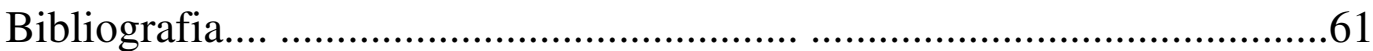

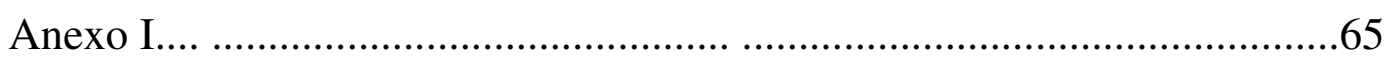

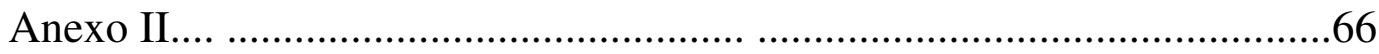




\section{Introdução}

É sobre um prosaico aspecto da vida social, a tributação, que recai o âmbito do presente trabalho. Pretende-se, aqui, fazer um estudo do princípio da capacidade contributiva na doutrina. Como princípio, a capacidade contributiva é mandamento nuclear de um sistema ${ }^{1}$, o sistema tributário; assim é mandamento porque jurídico, isto é, carregado de força normativa, portanto oponível como fundamento de um direito ao próprio Estado; e nuclear porque fundante, estruturante, do sistema. Como tal, o princípio repercute no sistema normativo, fulminando por invalidez os preceitos a ele contrários.

Essa monografia não se preocupa, entretanto, com a resolução de conflitos de normas em face de casos concretos, função típica do Judiciário; buscamos aqui, após delinear na doutrina (por José Domingues de Oliveira, Aliomar Baleeiro e Ricardo Lobo Torres, principalmente) o conceito de capacidade contributiva, identificar suas implicações para a formulação da política tributária, o que nos permitirá realizar um estudo da tributação no Brasil (nesse aspecto recorremos tanto à doutrina jurídica como a estudos interdisciplinares do Instituto de Pesquisa Econômica Aplicada e da Secretaria da Receita Federal) para verificar, à luz desses pressupostos, o grau de concretude e efetividade de que goza este princípio no sistema de tributação do país (com auxílio de diversas monografias sobre o tema).

Queremos destacar, em especial, o postulado da progressividade, refinamento do princípio da capacidade contributiva; fabricados ambos sob a égide de outro mandamento do direito, mais abstrato, o da igualdade. Este, o princípio que restaura, na desigualdade material, a justiça, por meio do tratamento desigual, na medida das desigualdades. No contexto de uma sociedade como a brasileira, profundamente desigual, e diante do objetivo

\footnotetext{
${ }^{1}$ MELLO, Celso Antônio de. Curso de direito administrativo, 23 a ed. São Paulo: Malheiros, p. 926-927.
} 
constitucional de redução da desigualdade econômico-social, pareceu-nos que o postulado da progressividade contém enorme potencial inaproveitado.

Partimos, entretanto, diante de um incômodo e incontroverso diagnóstico: o Brasil detém uma estrutura tributária brutalmente regressiva, isto é, quanto menor a renda do contribuinte, maior a proporção dela comprometida pela tributação; quanto mais expressivos seus rendimentos, menos pagará de tributo, proporcionalmente. Isso tem, obviamente, efeitos muito nocivos para a qualidade de vida da maior parte da população, chegando a comprometer sua subsistência, ao retirar-lhe parte substancial da renda através, principalmente, da pesada incidência dos tributos chamados indiretos.

O debate nos levará, também, a expor sobre o direito ao direito ao "mínimo existencial”, com base na formulação de Ricardo Lobo Torres, que, embora insuficiente se comparada ao marco de direitos previsto na Constituição Federal de 1988, serve-nos ao propósito de analisar a situação da tributação no Brasil, que como se verá, é contrária ao princípio da capacidade contributiva, porque francamente regressiva.

Pareceu-nos, em suma, que a efetivação do princípio da capacidade contributiva e de seu refinamento da progressividade, no sistema tributário brasileiro ainda é muito incipiente, impressão esta que pôde ser comprovada ao longo da pesquisa. Tornar a tributação justa significaria fazê-la curvar-se ao referido princípio, transformando a estrutura atual de incidência regressiva em uma estrutura progressiva.

Entretanto a doutrina tributarista, entre nós com especial afinco, mas também lá fora, durante muito tempo pretendeu conter o princípio da capacidade contributiva, relegando-o a um papel secundário ${ }^{2}$, imputandolhe, por vezes, a pecha de "ajurídico", porque de conteúdo indeterminado. Reabilitar o princípio da capacidade contributiva acarretará em elevar seu

\footnotetext{
${ }^{2}$ Leia-se, a respeito, em OLIVEIRA, José Marcos Domingues de. Direito tributário: Capacidade contributiva: conteúdo e eficácia do princípio, $2^{\mathrm{a}}$ ed. Rio de Janeiro: Renovar, 1998, p. 40.
} 
mais sofisticado sub-princípio, o da progressividade, a fundamento da estrutura tributária. Francamente vocacionado à construção de uma tributação distributivista, quedou por muito tempo alvo das críticas mais aguerridas, contra as quais parece agora se soerguer.

A monografia está organizada em três capítulos, o primeiro dedicado a um estudo doutrinário do princípio da capacidade contributiva. Nesse primeiro capítulo, veremos como ele representa a concretização do princípio da igualdade na tributação. Explicitaremos a legitimidade do tratamento desigual que o preceito contém, no contexto de uma diretriz constitucional distributivista. Em seguida, adentrando mais detidamente o conceito, vamos estudá-lo, sucessivamente, em seus três elementos constitutivos: em 1.1., como pressuposto e critério de graduação da tributação; em 1.2., como limite ao poder de tributar. Nesse tópico, abordaremos, também, o debate sobre o direito ao mínimo existencial, para, logo após, comparar este conceito doutrinário ao marco constitucional (1.3). O próximo passo, já exposto o conteúdo do princípio da capacidade contributiva, será estudar seus quatro subprincípios típicos, em 1.4: a progressividade, a proporcionalidade, a seletividade e personalização (deixando o tratamento do primeiro deles para o Capítulo 2, somente). Poderemos em seguida, encerrado o conteúdo doutrinário, expor, ao final do capítulo (1.5), a trajetória do princípio no direito constitucional positivo.

O segundo capítulo nos levará a um aprofundamento do conteúdo do postulado da progressividade, decorrência do princípio da capacidade contributiva. Após definir o que seja uma estrutura progressiva, abordamos as críticas que se formulam constantemente contra este padrão de tributação, no campo do direito, mas, também, na economia. Às críticas seguir-se-á a defesa da progressividade, recorrendo à doutrina variada. Estudando o conteúdo da progressividade, poderemos identificar o tratamento discriminatório legítimo que este postulado contém, e sua adequação à diretriz constitucional distributiva, quando poderemos, afinal, 
refutar a ideia de neutralidade da tributação, e defender a conformação do sistema tributário à progressividade.

O Capítulo 3 volta-se, em primeiro lugar, às implicações do princípio da capacidade contributiva para a boa formulação de uma política tributária (3.1). Neste tópico, estudaremos como ocorre a conformação do sistema tributário ao referido princípio, tanto de uma forma geral, quanto no que toca a um contribuinte em particular, atentando para os cuidados que se deve ter na análise desta adequação, em virtude de fenômenos como o da repercussão tributária e o da extrafiscalidade. Também estudaremos como ocorre a aplicação dos diferentes subprincípios da capacidade contributiva à política tributária, diante de espécies tributárias em concreto.

Em seguida no Capítulo 3, em sua segunda e última parte (3.2), analisamos, enfim, o caso particular do sistema tributário brasileiro. Partindo do reconhecimento do caráter regressivo de sua estrutura, percorremos brevemente o sentido e as características das reformas tributárias da década de 1960. Seguindo na pesquisa, indicamos as características do sistema que, hoje, atuam em reforço ao padrão regressivo geral, explicitando cada uma dessas características, nos tópicos de 3.2.1. a 3.2.3. Em 3.2.1, analisamos a grande participação dos tributos sobre produtos na arrecadação total; no tópico 3.2.2, a reduzida participação dos tributos diretos sobre a renda, propriedade ou capital na arrecadação total, e, por fim, em 3.3.3, a estrutura inadequada dos tributos diretos sobre a renda, propriedade ou capital, que é, predominantemente, proporcional. Esse último tópico sobre a estrutura de incidência nos tributos diretos merecerá um maior detalhamento, pois analisaremos a estrutura existente em quatro espécies tributárias em concreto: o Imposto Predial Territorial Urbano (3.2.3.1), quando trataremos do antigo entendimento do Supremo Tribunal Federal contrário à progressividade dos tributos ditos reais, representativo de uma postura da doutrina de contenção à eficácia da capacidade contributiva, e, enfim, expondo a superação deste entendimento pela via da Emenda à Constituição; do Imposto de Transmissão de Bens Móveis e 
Imóveis por Causa Mortis ou Doação trataremos em 3.2.3.2, do Imposto Territorial Rural em 3.2.3.3 e, por fim, do Imposto sobre a Renda em 3.2.3.3. Ao último capítulo se segue nossa conclusão sobre a pesquisa monográfica. 


\section{O princípio da capacidade contributiva}

O poder-dever do Estado de tributar os cidadãos somente se exerce de forma legítima quando o sistema tributário sobre o qual se assenta essa prerrogativa respeita o princípio da capacidade contributiva. Assim, a esta prerrogativa do Estado corresponde, necessariamente, sua sujeição ao referido princípio, que tutela os direitos individuais das pessoas ${ }^{3}$. O poder de tributar só se pode realizar informado pelo conteúdo do princípio da capacidade contributiva; de modo que o estudo deste conceito é determinante para a formulação de um juízo de valor acerca da política tributária de um país, que procure julgar seu caráter mais ou menos legítimo.

Em um Estado, como o brasileiro, que reconheça a abissal desigualdade sócio-econômica existente na sociedade e se proponha a reduzi-la (Art. 30 , III, da Constituição Federal) - objetivo republicano fundamental - o princípio da capacidade contributiva, concretização do princípio da igualdade no campo da tributação, parece ofertar um caminho seguro para esta redução:

Entendemos que no Direito Tributário a Igualdade se realiza através do princípio da capacidade contributiva, porque somente após garantida a satisfação das necessidades mínimas, comuns a todos, é que, ao depois, se poderá tratar desigualmente os desiguais, discriminando-os licitamente com base nas respectivas riquezas diversas $^{4}$ (grifos nossos).

A instituição de tratamentos jurídicos diferenciados, com lastro na diversidade entre as capacidades econômicas, pode restaurar, na desigual realidade social, o estatuto da igualdade, em cumprimento à diretriz constitucional. Nosso direito positivo já oferece fundamento a esta possibilidade, quando lemos a contrario sensu o seguinte dispositivo Constituição Federal:

\footnotetext{
3 Trata-se da aplicação, à administração tributária, do binômio "prerrogativas da administração direitos dos administrados", núcleo do regime jurídico administrativo segundo MELLO, Celso Antônio Bandeira de. Curso de direito administrativo. 23ª ed. São Paulo: Malheiros, p. 54-55.

${ }^{4}$ OLIVEIRA, José Domingues de. Capacidade contributiva: conteúdo e eficácia do princípio. Rio de Janeiro: Renovar, 1988, p. 35.
} 
Art. 150. Sem prejuízo de outras garantias asseguradas ao contribuinte, é vedado à União, aos Estados, ao Distrito Federal e aos Municípios: (...) II - instituir tratamento desigual entre contribuintes que se encontrem em situação equivalente, proibida qualquer distinção em razão de ocupação profissional ou função por eles exercida, independentemente da denominação jurídica dos rendimentos, títulos ou direitos (grifo nosso).

A fim de esclarecer a influência do princípio da igualdade sobre o princípio setorial da capacidade contributiva, devemos explicitar seu conteúdo. Em poucas palavras, o princípio expressa a capacidade econômica de suportar uma correspondente contribuição aos gastos públicos. Essa contribuição, exigida e graduada pelo Estado, não pode comprometer a capacidade empresarial ou a subsistência do indivíduo. A definição que apresentamos busca resumir as lições colhidas na doutrina por José Domingues Oliveira em sua excelente monografia ${ }^{5}$, exprimindo a capacidade contributiva como (i) pressuposto da tributação, (ii) critério de graduação da tributação e (iii) limites ao poder de tributar; seus três elementos constitutivos:

O princípio da capacidade contributiva se apresenta, assim, segundo Sainz de Bujanda, como pressuposto ou fundamento do fato gerador (...). Mas, aduza-se, o princípio atua também como critério de graduação dos tributos informando a progressividade, que enseja a realização da igualdade de 'sacrifício fiscal relativo' de que falava Stuart Mill. Outrossim, se é exato que somente uma situação que reflita alguma capacidade de tributação, não é menos correto que a pessoa que nela se encontre não pode, em razão disso, ser tributada num tal nível que o impeça de continuar a exercer atividade lícita, ou que lhe retire o indispensável a uma vida digna, ou que reduza o 'padrão do contribuinte' (capacidade contributiva como limite da tributação) ${ }^{6}$.

Passamos, agora, a aprofundar o debate em torno do conteúdo do princípio, considerando-o, primeiro, enquanto pressuposto e critério de graduação do ônus tributário.

\subsection{A capacidade econômica do indivíduo como pressuposto e como critério de graduação do ônus tributário}

\footnotetext{
${ }^{5}$ Em nosso estudo, recorremos a duas edições da obra, alternadamente: OLIVEIRA, José Domingues de. Capacidade contributiva: conteúdo e eficácia do princípio. Rio de Janeiro: Renovar, 1988 e OLIVEIRA, José Domingues de. Capacidade contributiva: conteúdo e eficácia do princípio, $2^{\mathrm{a}}$ ed. Rio de Janeiro: Renovar, 1998. No que toca à definição apresentada, remetemos, principalmente, ao capítulo $\mathrm{V}$ - Conteúdo do princípio.

${ }^{6}$ OLIVEIRA, José Domingues de. Op. cit., 1988, p. 38.
} 
Preliminarmente, é importante notar o fundamento ético da tributação: tendo o indivíduo a possibilidade de contribuir para o sustento material da coletividade, essa circunstância se transforma no dever de fazê$10^{7}$. Não o fizesse, estaria se locupletando da contribuição dos demais, pois, em contrapartida, pela simples circunstância de viver em sociedade já percebe um benefício. Adam Smith já admitia, como fundamento da capacidade contributiva, essa vantagem para o indivíduo na constituição da comunidade política:

Os súditos de cada Estado devem contribuir o máximo possível para a manutenção do Governo, em proporção a suas respectivas capacidades, isto é, em proporção ao rendimento de que cada um desfruta, sob a proteção do Estado ${ }^{8}$ (grifo nosso).

Paralelamente a essas considerações de ordem ética, há a capacidade contributiva como pressuposto de fato da tributação; o sempre citado Aliomar Baleeiro afirmava que, em última análise, o indivíduo paga o tributo porque tem capacidade contributiva ${ }^{9}$. A capacidade econômica do indivíduo fornece, assim, a causa material da tributação. Se o contribuinte não ostentar capacidade econômica, qualquer exigência tributária lhe será inócua, por lhe faltar o substrato fático.

A capacidade econômica como pressuposto da tributação expressa a chamada dimensão objetiva do princípio da capacidade contributiva; a qual se contrapõe à subjetiva, evidenciada no momento de graduação do tributo, quando se atenta para as condições individuais do contribuinte ${ }^{10}$.

Assim, o princípio estudado impõe-se, também, como critério de graduação da tributação dirigido ao Estado, o qual não poderá tributar à revelia da capacidade econômica do indivíduo; constituindo esta o critério

\footnotetext{
${ }^{7}$ OLIVEIRA, José Marcos Domingues de. Direito tributário: capacidade contributiva: conteúdo e eficácia do princípio, $2^{\text {a }}$ ed. Rio de Janeiro: Renovar, 1998, p. 7.

${ }^{8}$ SMITH, Adam, Investigação sobre a natureza e as causas da riqueza das nações. Tradução de Luiz João Baraúna, $3^{\text {a }}$ ed., vol. III (coleção os economistas). São Paulo: Nova Cultural, 1988, p. 99.

${ }^{9}$ BALEEIRO, Aliomar. Limitações ao poder de tributar, $5^{\mathrm{a}}$ ed., ver. de acordo com a Emenda Constitucional n. ${ }^{\circ}$ 1, de 1969, e com o C.T.N. Rio de Janeiro: Forense, 1977, p. 357

${ }^{10}$ OLIVEIRA, José Domingues de. Op. cit., 1988, p. 36.
} 
de mensuração por excelência do quantum devido. No processo, o Estado vale-se dos índices manifestados de capacidade contributiva do indivíduo, que não se restringem somente à renda, isto é, ao fluxo de dinheiro percebido pelo indivíduo periodicamente a título de remuneração pela utilização de fatores de produção de sua propriedade (tipicamente, capital e/ou trabalho). A expressão econômica do indivíduo abrange, hoje, também, seu patrimônio (ou riqueza, aqui usados indistintamente).

Não importa, por exemplo, que determinado bem esteja "entesourado", isto é, não gere qualquer rendimento para o indivíduo. Para ilustrar o ponto, tomemos a contribuição de melhoria, tributo devido pelo proprietário de imóvel em virtude de valorização decorrente de obra pública. Para que o tributo incida, não é necessário que o bem seja explorado economicamente; tampouco que a valorização imobiliária tenha sido percebida financeiramente pelo proprietário ${ }^{11}$. Basta que o bem imóvel, integrando o patrimônio do contribuinte, valorize-se, ainda que não gere renda ou tampouco o ganho de capital seja realizado. Assim, a mera valorização do bem imóvel justifica o tributo, porque maior sua capacidade contributiva. Temos, com isso, um incremento na

capacidade de pagar (ability to pay) como dizem os povos de língua inglesa. Significa que cada um deve contribuir na proporção de suas rendas e haveres, independentemente de sua eventual disponibilidade financeira $^{12}$ (grifo nosso).

Podemos, enfim, analisar o último elemento constitutivo conceito, que expressa, na forma de duas modalidades de imunidades tributárias, os limites ao poder de tributar decorrentes do princípio.

\subsection{A capacidade econômica tributável: limites ao poder de tributar e direito ao "mínimo existencial"}

\footnotetext{
${ }_{11}^{11}$ Nesse sentido, OLIVEIRA, José Domingues de. Op. cit., 1998, p. 36.

12 TORRES, Ricardo Lobo. Curso de direito financeiro e tributário, $12^{\mathrm{a}}$ ed. Rio de Janeiro: Renovar, 2005, p. 93-94.
} 
Não basta para a caracterização do princípio que se ressalte a capacidade econômica como pressuposto e critério de graduação da imposição tributária; é preciso qualificar esta capacidade. Somente a parcela tributável pelo Estado é que poderá ser considerada; da capacidade econômica total, deve-se abstrair um quantum imune à tributação.

Essa imunidade é decorrência da necessidade de preservação da capacidade de subsistência do indivíduo, bem como de sua capacidade empresarial. Trata-se de exigência que qualifica o que se entenda por capacidade econômica do indivíduo - antes, é capacidade econômica tributável. E tributável será, desde que, subtraída uma fração em favor do Estado, não se comprometa a subsistência do indivíduo, quer dizer, sua capacidade de prover para si mesmo e sua família condições dignas de existência; bem como sua capacidade empresarial.

Deve-se entender capacidade empresarial como capacidade de explorar atividade econômica; sua imunidade, portanto, consiste na preservação da capacidade do indivíduo de lançar-se em uma empresa, no sentido de atividade de produção de bens ou serviços para a coletividade; não se pode confundir com uma imunidade tributária da atividade empresarial, que não existe. O que é imune é somente a capacidade do indivíduo de engajar-se nela.

Essa imunidade da capacidade empresarial abrange um aspecto que é, por vezes, desconsiderado - o da proteção ao trabalho. O direito ao trabalho, tomado em sentido amplo, compreende o direito a empreender - e, não raro, o trabalhador é um pequeno capitalista, que emprega seu diminuto capital na exploração de alguma atividade econômica (a exemplo dos incontáveis ambulantes, verdadeiros micro-empresários, que trabalham nas ruas das cidades brasileiras). A imunidade tributária da capacidade empresarial, pois, serve-lhe aí de esteio protetor, a recomendar, entre outras 
medidas, a drástica redução dos tributos indiretos ${ }^{13}$, que tanto sufocam sua atividade.

Quanto à imunidade da capacidade de provimento da subsistência, trata-se de aspecto que importa mais a esta monografia, uma vez que entender a capacidade contributiva como limite ao poder de tributar, na forma dessa imunidade tributária da capacidade de subsistência, permite adentrar o debate acerca do direito ao "mínimo existencial".

Essa imunidade tributária impede que o Estado, ao tributar, comprometa o alcance de um padrão mínimo de subsistência, a partir do qual se garantiria a vida digna para o indivíduo e sua família. O problema, evidentemente, está na determinação deste padrão mínimo, pois o debate sobre o paradigma da "subsistência" ou sobre as condições mínimas de vida envolve um conflito político de ordem distributiva considerável; importante para nós, entretanto, é reconhecer seu caráter relativo, porque determinado pelo tempo histórico e pela sociedade em questão ${ }^{14}$.

Entre os esforços doutrinários de delimitação do conceito, destacamos o de Ricardo Lobo Torres. Na formulação do autor, o direito ao "mínimo existencial" compreenderia um espectro de atividades do Estado e direitos que, relativamente ao amplo panorama de direitos sociais previsto no marco constitucional (essa comparação será explicitada mais adiante), pode ser considerado bastante insuficiente. Não obstante esta limitação, sua concepção deve ser considerada, por ter sido um dos primeiros autores a escrever, no Brasil, sobre o direito ao mínimo existencial

entendido como o direito às condições mínimas de existência humana digna, que não tem diç̧ão constitucional própria, é imune a tributos e ainda exige as prestações estatais positivas. Tem por fundamento as

\footnotetext{
${ }^{13}$ Para um detalhamento sobre o tributo indireto, ver 3.1.

${ }^{14}$ Sociedades mais antigas toleram um padrão mínimo de condições materiais seria insuportável nos dias de hoje. Também nós, hoje, parecemos conviver com um padrão mínimo de subsistência consideravelmente inferior àquele observado em sociedades mais civilizadas.
} 
condições da liberdade, a busca da felicidade, a igualdade e o respeito à dignidade humana ${ }^{15}$.

O conceito de direito ao mínimo existencial formulado pelo autor compreende determinadas prestações positivas do Estado, desde as mais clássicas (como Justiça, segurança e diplomacia), até a garantia de alguns poucos direitos sociais básicos (educação primária, saúde, segurodesemprego). Além disso, o autor não reconhece aos direitos sociais o status de direito fundamental; e esta classificação não passaria de uma controvérsia terminológica de interesse meramente acadêmico não houvesse uma consequência importante: por não constituírem direitos fundamentais, os direitos sociais, segundo Lobo Torres, não seriam, em regra, exigíveis do Estado, que poderia lhes opor a chamada reserva do possível; ao passo que tão somente os direitos fundamentais assumiriam o status de direitos públicos subjetivos, oponíveis ao Estado.

Apesar das críticas dirigidas ao conceito de direito ao mínimo existencial de Ricardo Lobo Torres, por desconsiderar o caráter fundamental dos direitos sociais ${ }^{16}$, e por abranger um espectro muito reduzido destes mesmos direitos, sua formulação serve ao propósito desta monografia de analisar a política tributária brasileira, com especial atenção ao princípio da capacidade contributiva.

No plano internacional, o direito ao mínimo existencial encontra expressão na Declaração Universal dos Direitos Humanos, de 1948, no art. 25, I:

\footnotetext{
${ }^{15}$ TORRES, Ricardo Lobo. Tratado de direito constitucional financeiro e tributário, v. III: os direitos humanos e a tributação: imunidades e isonomia. Rio de Janeiro: Renovar, p. 486.

${ }^{16}$ A doutrina constitucionalista questiona, hoje, fortemente, essa concepção; por todos, SILVA, José Afonso da. Curso de direito constitucional positivo, $26^{\mathrm{a} e d}$. São Paulo: Malheiros, p. $184 \mathrm{e}$ 286, para quem "os direitos sociais, como dimensão dos direitos fundamentais do homem, são prestações positivas proporcionadas pelo Estado direta ou indiretamente, enunciadas em normas constitucionais, que possibilitam melhores condições de vida aos mais fracos, direitos que tendem a realizar a igualização de situações sociais desiguais". A interpretação restritiva que alguns buscam imprimir aos direitos sociais parece caminhar, inclusive, de encontro à letra da Constituição, eis que o Capítulo II - Direitos Sociais integra o Título II - Dos Direitos e Garantias Fundamentais.
} 
Todo homem tem direito a um padrão de vida capaz de assegurar a si e a sua família saúde e bem-estar, inclusive alimentação, vestuário, habitação, cuidados médicos e os serviços sociais indispensáveis, e direito à segurança em caso de desemprego, doença, invalidez, viuvez, velhice ou outros casos de perda de meios de subsistência em circunstâncias fora de seu controle (grifos nossos).

A redação do dispositivo, avanço civilizatório inegável, carrega, contudo, a prudência típica das normas internacionais. Em primeiro lugar, lê-se que a proteção contra situações de vulnerabilidade social, além daquelas citadas expressamente, será provida somente se indivíduo não tiver dado causa à perda dos meios de subsistência ${ }^{17}$. Em segundo, os "serviços" (não os direitos) sociais assegurados são somente os “indispensáveis”. Claramente, indica-se um padrão apenas mínimo de vida a ser garantido.

A definição de Ricardo Lobo Torres, portanto, está conforme ao paradigma normativo internacional, e não busca sua ampliação; sendo ambas de corte conservador, especialmente se consideramos o nível de vida das populações nos países mais avançados.

\subsection{A Constituição de 1988: maximizando o direito ao "mínimo" existencial}

A Constituição de 1988 parece ter ido algo além dos paradigmas de direito ao "mínimo existencial" formulados tanto por Ricardo Lobo Torres em sua doutrina quanto pela Declaração Universal dos Direitos Humanos no dispositivo citado. Não obstante a inexistência de uma cláusula geral de direito ao mínimo existencial e de sua correspondente imunidade tributária; desde o onipresente princípio da dignidade da pessoa humana, fundamento da República (Art. $1^{\circ}$, III), até a Carta de Direitos, o Texto Magno conspira

\footnotetext{
${ }^{17}$ A partir de uma leitura a contrario sensu do dispositivo: quando a situação de vulnerabilidade estiver sob controle do indivíduo, poderá ser imputada a este, caso em que o Estado ou a coletividade se eximem de prover sua subsistência. Nas situações citadas (doença, invalidez, viuvez, desemprego e velhice), ao contrário, a redação do dispositivo não parece permitir a exclusão da responsabilidade do Estado a título de culpa do indivíduo.
} 
para que se assegure à pessoa humana "condições mínimas de existência humana digna" 18 .

Exemplificando o argumento, passamos a citar dispositivos da Constituição representativos de um contexto de ampliação do conteúdo do direito ao mínimo existencial na Constituição de 1988, se comparada à concepção de Ricardo Lobo Torres, reputada das mais autorizadas neste campo, e à norma internacional contida na Declaração Universal:

- Realização de um Estado de Direito, espaço da liberdade e da igualdade, mediante, principalmente, o disposto no art. $5^{\circ}$;

- Reconhecimento dos direitos sociais - quase todo o rol do art. $6^{\circ}$ ao $9^{\circ}$ reflete a ratio inerente ao direito ao mínimo existencial. Entre os mais paradigmáticos, citamos: o direito ao Salário Mínimo "capaz de atender a suas necessidades vitais básicas e às de sua família com moradia, alimentação, educação, saúde, lazer, vestuário, higiene, transporte e previdência social" (Art. $\left.7^{\circ}, \mathrm{IV}\right)$; o direito à proteção da relação de emprego (Art. $7^{\circ}, \mathrm{I}, \mathrm{VI}, \mathrm{VII}, \mathrm{XX}, \mathrm{XXVII}$ ); o direito ao seguro-desemprego (Art. $7^{\mathrm{o}}$, II) e ao Fundo de Garantia por Tempo de Serviço (Art. $7^{\circ}$, III). Registramos, também, a positivação dos direitos à saúde, à previdência, e à assistência social, reunidos no capítulo II da Ordem Social, que trata do sistema de seguridade social, destinado a assegurá-los (art. 194). Quanto ao direito à educação, a Constituição procura, por exemplo, prover mais que apenas a educação primária, quando determina a progressiva universalização do Ensino Médio (Art. 208, II) e o acesso aos níveis mais elevados de Ensino (Art. 208, V), prevendo, inclusive, o provimento da Educação Superior pelo próprio Estado (Art. 207).

- Ao atribuir o status de direito fundamental aos direitos sociais contrariamente ao entendimento de Ricardo Lobo Torres - razão pela qual

\footnotetext{
${ }^{18}$ TORRES, Ricardo Lobo. Op. cit., p. 486.
} 
passam a constituir direitos públicos subjetivos, oponíveis ao Estado e exigíveis dele, compondo, ainda, o núcleo imodificável da Constituição (Art. 60, $\left.\S 4^{\circ}, \mathrm{IV}\right)$;

- A Constituição dispõe, ainda, sobre o princípio da seletividade em tributos indiretos (Arts. 153, IV, $\S 3^{\circ}$, I, para o IPI; 153, II, $\S 2^{\circ}$, III, para o ICMS); sobre a imunidade tributária da pequena propriedade quanto ao ITR

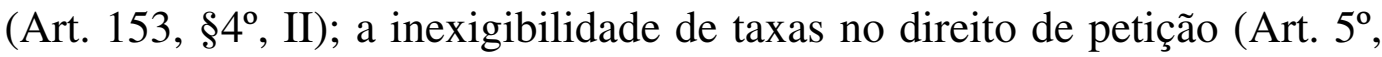
XXXIV); a isenção de custas na Ação Popular (Art. 5, LXXIII); a assistência jurídica gratuita para os pobres (Art. $5^{\circ}$, LXXIV); a gratuidade dos Registros Civis para os pobres (Art. 5 ${ }^{\circ}$ LXXVI); e a gratuidade das Ações Constitucionais (Art. 5 ${ }^{\circ}$ LXXVII).

Após essa digressão em torno do direito ao mínimo existencial, retomemos o princípio da capacidade contributiva. Apresentados seus três elementos constitutivos (pressuposto e critério de graduação da tributação e limite ao poder de tributar), podemos analisar os postulados que dele decorrem, os quais serão essenciais quando abordarmos as implicações do princípio para uma boa política tributária, e, posteriormente, a análise do caso particular da tributação no Brasil.

\subsection{Decorrências do princípio da capacidade contributiva: progressividade, proporcionalidade, seletividade e personalização}

Colocar o princípio da capacidade contributiva e o postulado da progressividade no centro do sistema tributário é o rumo adequado a um Estado distributivista, voltado à redução da desigualdade sócio-econômica:

Para que o direito tributário seja um dos instrumentos de promoção da distribuição da riqueza, a eficácia e o conteúdo devem ser aprofundados no sentido de que ele [o princípio da capacidade contributiva] deve não apenas ser considerado válido, mas que sua validez se estenda a todo o sistema tributário, bem como que o recolhimento das contribuições aumente não apenas proporcionalmente e sim progressivamente, na medida em que a riqueza individual aumenta. Isto significa retirar o princípio de sua localização ainda secundária em nosso ordenamento e 
colocá-lo numa posição mais privilegiada, ao lado de importantes princípios como é o da legalidade ${ }^{19}$.

Em um debate sobre política tributária e sobre a distribuição da carga tributária pela população, atentando para a maior ou menor legitimidade do sistema, face às exigências constitucionais de observância do princípio da igualdade e da capacidade contributiva, devemos assinalar a importância de analisar as diversas formas pela qual este princípio pode se manifestar. Ricardo Lobo Torres identifica quatro postulados decorrentes da capacidade contributiva, descrevendo-os um a $\mathrm{um}^{20}$ : a proporcionalidade, a progressividade, a personalização e a seletividade. O centro de nossas atenções, neste trabalho, é a progressividade, objeto de uma análise mais aprofundada no próximo capítulo; uma breve explanação sobre os demais, entretanto, é pertinente.

Na proporcionalidade, o gravame tributário deve ser estabelecido em proporção à sua base de cálculo segundo uma alíquota fixa, que não se altere na medida em que aumente o montante desta base. Como exemplo, ressaltamos: um proprietário de imóvel urbano muito valioso, assim como um magistrado aposentado com elevados vencimentos, devem pagar idêntica alíquota ad valorem incidente sobre as suas propriedade imóvel (IPTU) e renda (IR), respectivamente, se comparados a um proprietário de modesto apartamento no subúrbio e um assalariado que ganhe três saláriosmínimos.

Não obstante às graves distorções quando utilizada como critério de graduação da tributação global nos dias atuais, a proporcionalidade constituiu-se, na alvorada do moderno Estado de Direito, inegável avanço civilizatório em relação às imunidades odiosas do Antigo Regime - “ $O$

\footnotetext{
${ }^{19}$ HETZEL, Moacir. Possibilidades e limites do direito tributário num processo de distribuição de renda, 1993. Dissertação (Mestrado) - Departamento de Ciências Jurídicas da PUC-Rio, p. 101.

${ }^{20}$ TORRES, Ricardo Lobo. Op. cit., p. 334-335 e 424-448.
} 
costume antigo era que o povo contribuísse com seus bens, a nobreza com seu sangue e o clero com suas preces" 21 .

A personalização, por sua vez, guarda íntima relação com o conteúdo imediato da capacidade contributiva, pois condiciona a incidência tributária à atenção às características pessoais do contribuinte, aí incluídas como elementos capazes de alterar a quantidade de tributo devido não só o montante e a composição de seu patrimônio ou renda (se a renda é decorrente do trabalho ou do capital; se de aplicações financeiras ou de aposentadoria), como seu padrão de gastos (quantos são seus dependentes, quanto gasta com saúde, educação, etc.). A personalização, como se vê, aproxima-se da capacidade contributiva, mas não se confunde com esta, mais ampla. Para Domingues Oliveira ${ }^{22}$,

surge o imposto pessoal como a tributação justa por excelência, pois é através dele que, preocupando-se a lei com as condições individuais do sujeito passivo, se enseja melhor pesquisa da efetiva idoneidade econômica do contribuinte para acudir à despesa pública sem sacrifício do indispensável à sua manutenção.

Outra decorrência do princípio da capacidade contributiva, o postulado da seletividade tem conteúdo ainda mais restrito, ao demandar que o fenômeno tributário desonere os bens e atividades considerados essenciais à coletividade, onerando em contrapartida aqueles não essenciais. Assim, o gravame tributário deve crescer na medida em que aumente a superfluidade dos bens e atividades tributados, decrescendo na medida em que sobreleve sua essencialidade. A essencialidade é aqui referida a tudo que respeita à subsistência, constituindo a superfluidade sua antítese. Neste sentido, "seletividade em função da essencialidade significa que o tributo

\footnotetext{
${ }^{21}$ HUGON, Paul. $O$ imposto. São Paulo: Renascença, 1945, p. 65. Apud OLIVEIRA, Op. cit., 1998, p. 15. À época, tributavas-e conforme o pertencimento a uma determinada classe social herdada. Clero e nobreza eram imunes à tributação, e todos os demais, onerados per capita - cada membro do chamado "terceiro estado" pagava a mesma quantidade de tributo, não importando se rico ou pobre; o que tornava o sistema ainda mais iníquo, porque regressivo.

${ }^{22}$ Op. cit., 1998, p. 84.
} 
recai sobre os bens na razão inversa de sua necessidade para o consumo popular e na razão direta de sua superfluidade" ${ }^{23}$.

Este subprincípio tem grande importância no contexto dos tributos indiretos, em especial no Brasil, dada a elevada participação desta espécie tributária na arrecadação do país, e sua forte incidência sobre bens e, em menor grau, serviços, de consumo de massa. Um sistema tributário verdadeiramente seletivo deveria, no último grau de essencialidade, isentar totalmente de tributação os bens mais importantes para a subsistência da população (por exemplo, os que compõem a "cesta básica") ${ }^{24}$.

É importante observar, também, no que respeita à seletividade, que Sacha Calmon Navarro Coelho recomenda cautela em sua aplicação ao Imposto sobre Produtos Industriais. Para o autor, neste imposto a seletividade em função da essencialidade dos bens e serviços ficaria comprometida em razão das necessidades da produção industrial e das políticas extrafiscais ${ }^{25}$ : "É o IPI um agente de intervenção na economia $e$ na livre concorrência, além de constituir barreira alfandegária, função reservada aos impostos aduaneiros" ${ }^{26}$. Sua observação é útil para ilustrarmos como esse tributo, tão importante para a arrecadação tributária do país, frequentemente submete-se a direcionamentos que não o da seletividade em sentido estrito, que se dá em função da essencialidade.

Explicitado, afinal, o princípio da capacidade contributiva em todos seus contornos doutrinários, passamos a estudá-lo sob a perspectiva do direito constitucional positivo.

\subsection{A trajetória constitucional do princípio da capacidade contributiva}

A Constituição de 1988 dispõe:

\footnotetext{
23 TORRES, Ricardo Lobo. Op. cit., p. 441.

${ }^{24}$ Pretendendo acolher o princípio da seletividade, a Constituição de 1946 assim dispôs: “Art. 15, $\$ 1^{\circ}$ São isentos do imposto de consumo os artigos que a lei classificar como o mínimo indispensável à habitação, vestuário, alimentação e tratamento médico das pessoas de restrita capacidade econômica".

${ }^{25}$ Para uma explicação mais detalhada do fenômeno da extrafiscalidade, ver 3.1.

${ }^{26}$ COELHO, Sacha Calmon Navarro. Comentários à constituição de 1988: sistema tributário, $8^{\mathrm{a}}$ ed. Rio de Janeiro: Forense, 1999, p. 375.
} 
Art. $145, \S 1^{\circ}$. Sempre que possível, os impostos terão caráter pessoal e serão graduados segundo a capacidade econômica do contribuinte, facultado à administração tributária, especialmente para conferir efetividade a esses objetivos, identificar, respeitados os direitos individuais e nos termos da lei, o patrimônio, os rendimentos e as atividades econômicas do contribuinte.

A Constituição acerta ao resumir nessa cláusula geral boa parte das lições da doutrina dantes referidas: a capacidade contributiva como critério de graduação do tributo; uma ampla compreensão acerca dos índices da capacidade contributiva - abrangendo não só a renda ("rendimentos") do contribuinte, como seu patrimônio e atividades econômicas; a contrapartida de sujeição do Estado à observância dos direitos individuais do contribuinte; o subprincípio da personalização.

Entretanto, o texto constitucional desvia-se da adequada positivação do princípio estudado ao iniciar o período por "sempre que possível". A localização dessa locução deu margem a infindáveis controvérsias sobre a eficácia e aplicabilidade do princípio da capacidade contributiva, com importantes repercussões, inclusive, sobre a jurisprudência do $\mathrm{STF}^{27}$. Outro deslize é a menção apenas aos "impostos" no sujeito do período, apesar de o princípio, como vórtice do sistema tributário, vincular qualquer espécie tributária.

A Constituição de 1946, primeira a incorporar a lição da ciência das finanças acerca da capacidade contributiva e da personalização, poderia ter fornecido paradigma mais seguro para os constituintes de 1988, pois não incorreu em nenhum dos dois equívocos apontados. Em seu art. 202, lê-se: "os tributos terão caráter pessoal sempre que isso for possível, e serão graduados conforme a capacidade econômica do contribuinte"; fala-se, portanto, em "tributos", e está claro que a relação da locução restritiva "sempre que possível" se estabelece, somente, com o subprincípio da personalização, e não com o princípio angular da capacidade contributiva.

\footnotetext{
${ }^{27}$ Conforme referido mais adiante, ao tratarmos do Imposto Predial Territorial Urbano no Capítulo
} 3. 
Aliomar Baleeiro reconhecia nesse dispositivo uma oportunidade de concertação entre as forças políticas antagônicas que se digladiavam no breve interregno democrático 1946-1964:

Numa Constituição resolvida a manter a propriedade privada e a disseminá-la, ainda que não infensa a nacionalizá-la, em caráter excepcional, o art. 202 representava confessadamente uma ponte oportunística de conciliação, em busca de introduzir o espírito reformista nas forças conservadoras ${ }^{28}$.

Oportunidade essa claramente abandonada pelas forças políticas que assumiram o poder com o Golpe Militar de 1964, que se apressaram em suprimir o princípio da capacidade contributiva do ordenamento do país, por meio da Emenda Constitucional 18/1965. O superveniente Código Tributário Nacional (Lei $\mathrm{n}^{\circ}$. 5.172/1966) não o reabilitou expressamente. A manutenção desta omissão no sistema $^{29}$ - não obviada em diploma que se pretendia sistemático e definitivo - muito mais que um preciosismo, tem clara pertinência com a série de reformas empreendidas pela Ditadura Militar, que desaguaram em um sistema tributário contrário ao princípio da capacidade contributiva, porque francamente regressivo, conforme teremos oportunidade de expor mais adiante, no Capítulo 3.

\footnotetext{
${ }^{28}$ BALEEIRO, Aliomar. Op. cit., p. 315.

29 Para BALEEIRO, Aliomar. Op. cit., 487-488, o princípio, embora revogado, permanecera implícito no sistema.
} 


\section{Refinando o princípio da capacidade contributiva: o postulado da progressividade}

Em uma estrutura progressiva de tributação,

a onerosidade relativa aumenta na medida do crescimento da renda. É esse o caso típico do imposto de renda das pessoas físicas, que não é mero tributo variável ou proporcional, mas um tributo progressivo. Não apenas quem ganha mais paga mais, mas paga progressivamente mais. Se alguém tem renda de 100, paga, por hipótese, 10; mas, se sua renda cresce para 200, ele não paga 20 e sim, por exemplo, 30 , porque sobre a nova porção da renda foi maior o quinhão destinado aos cofres públicos ${ }^{30}$.

A tributação progressiva envolve um tratamento diferenciado entre contribuintes que detêm capacidades econômicas tributáveis diferentes. Neste sentido, Ricardo Lobo Torres reconhece legitimidade às discriminações baseadas na capacidade contributiva:

Sendo essencialmente discriminatório o direito tributário, só a distinção odiosa ou desarrazoada, apoiada em circunstâncias estranhas à capacidade contributiva, ao custo/benefício, ao desenvolvimento econômico, aos direitos humanos (...) é que fere a liberdade e se torna inconstitucional. As discriminações reversas cometidas contra os ricos e os fortes e em favor dos pobres e dos fracos - são legítimas. ${ }^{31}$ (grifos nossos).

Escrevendo em uma época marcada pelo dogmatismo e pela polarização ideológica -, Aliomar Baleeiro já percebia a potencialidade da progressividade:

Arma política de eficiência comprovada, o imposto pessoal e progressivo poderá ser o instrumento surdo e adequado a uma revolução social, sem 'sangue, suor ou lágrimas', mas tão radical quanto as de caráter catastrófico que têm congestionado cemitérios, cárceres e orfanatos, apavorando as sociedades ameaçadas pela sua propagação insinuante e insidiosa $^{32}$.

Contra a progressividade, com frequência, levantam-se as mais variadas críticas, tanto de ordem jurídica como as de fundo econômico. Dessas últimas trataremos, com brevidade, mais adiante. No campo do direito, grosso modo, as críticas afirmam que os impostos progressivos violariam o ordenamento, e, em particular, os preceitos da (i) vedação do confisco no direito tributário e da (ii) isonomia.

\footnotetext{
${ }^{30}$ AMARO, Luciano. Direito tributário brasileiro, $14^{\text {a }}$ ed. São Paulo: Saraiva, 2008, p. 91.

${ }^{31}$ TORRES, Ricardo Lobo. Op. cit., p. 491.

${ }^{32}$ BALEEIRO, Aliomar. Op. cit., p. 308.
} 
Quanto ao primeiro deles, objeta à progressividade o art. 150, IV, da Constituição, que proíbe os entes federados de "utilizar tributo com efeito de confisco". A este respeito, registre-se que, no direito tributário, confiscar significa elevar-se a tributação a um nível tal que consoma a renda ou a riqueza do contribuinte. Esta absorção, contudo, é indireta, porque não implica na expropriação, quer dizer, na transferência imediata para o Estado, da propriedade ou da renda; o que ocorre é que se compele o contribuinte, em virtude da tributação exagerada, a desfazer-se de seu patrimônio, com o objetivo de fazer frente à exigência tributária - por isso a Constituição fala em tributo com efeito de confisco. Vê-se, assim, que o confisco no direito tributário é, na verdade, um confisco indireto, que se realiza pela via transversa da tributação, não provocando de imediato a perda do bem ou da renda.

Esclarecido este ponto, estamos com Sacha Calmon Navarro Coelho $^{33}$, para quem a vedação do confisco no direito tributário adquire ares de um "princípio da razoabilidade" na graduação do tributo. Em contradita à crítica formulada à progressividade, o autor afirma, supondo uma progressividade por faixas em um imposto sobre a renda, que sequer uma alíquota máxima graduada em $100 \%$ violaria a proibição do confisco; isto porque ainda assim não haveria absorção total da renda, já que uma parcela significativa desta estará exposta às alíquotas menores das faixas anteriores, chegando, na primeira delas, até a isenção. Ter-se-ia, assim, uma tributação total sempre menor que $100 \%$, ainda que a alíquota máxima alcance esse valor. É importante notar, contudo, que o limite para a alíquota máxima é justamente os 100\%; ultrapassar esse limite viabilizaria a absorção total da renda, e, portanto, o confisco, o que é vedado.

No campo da chamada extrafiscalidade ${ }^{34}$, entretanto, a relação da tributação progressiva com a proibição do confisco muda significativamente. Sempre que incidir um objetivo extrafiscal válido, que

\footnotetext{
${ }^{33}$ COELHO, Sacha Calmon Navarro. Op. cit., p. 315.

${ }^{34}$ Para uma definição de extrafiscalidade, ver 3.1.
} 
justifique a tributação progressiva, não cabe opor a esta a proibição do confisco, que só tem lugar no campo da fiscalidade. É, novamente, Sacha Calmon quem dá o alerta, em passagem eloquente, a qual, apesar de longa, pedimos licença para reproduzir. Esse entendimento será fundamental, mais adiante, na crítica que faremos à antiga orientação do Supremo Tribunal Federal acerca da tributação progressiva.

Aqui dá-se um aparente paradoxo. É exatamente no escopo de tornar insuportável a propriedade utilizada contra a função social que são arrumadas as tributações extrafiscais. $\mathrm{O}$ imposto territorial rural exacerbado leva o proprietário egoísta a desfazer-se dela ou dar-lhe função compatível com a CF. O IPTU progressivo no tempo leva o proprietário de lotes urbanos inaproveitados ao desespero. O imposto de importação altíssimo desestimula o consumo de bens supérfluos (...). Em suma, a vedação do confisco há de se entender um modus in rebus. $\mathrm{O}$ princípio tem validade e serve de garantia (...). O princípio, vê-se, cede o passo às políticas tributárias extrafiscais, mormente as expressamente previstas na Constituição. Quer dizer, onde o constituinte previu a exacerbação da tributação para induzir comportamentos desejados ou inibir comportamentos indesejados, é vedada a arguição do princípio do não-confisco tributário, a não ser no caso-limite (absorção do bem ou da renda). Destarte, se há fiscalidade e extrafiscalidade e se a extrafiscalidade adota a progressividade exacerbada para atingir seus fins, deduz-se que o princípio do não-confisco atua no campo da fiscalidade tão-somente e daí não sai, sob pena de antagonismo normativo, um absurdo lógico-jurídico ${ }^{35}$.

O secundo preceito supostamente violado, segundo os críticos da progressividade seria a isonomia. A progressividade violaria a igualdade, por um lado, simplesmente em razão de discriminar cidadãos; ideia esta gestada sob uma concepção datada do princípio da igualdade, que o considera exclusivamente em seu aspecto formal, e que já não encontra fundamento em nosso sistema constitucional. Por outro lado, essa crítica, em uma versão mais sofisticada, defende que a progressividade violaria a igualdade por exigir progressivamente mais tributos de alguns cidadãos, discriminando-os para além do nível tido por suficiente para compensar a desigualdade de capacidades existente entre os contribuintes. A progressividade trataria desigualmente aos desiguais, mas extrapolando o que seria adequado diante da medida entre as suas desigualdades. Esses críticos enxergam na proporcionalidade - que já exige dos mais ricos o

\footnotetext{
${ }^{35}$ COELHO, Sacha Calmon Navarro. Op. cit., p. 253.
} 
pagamento de mais tributo -, o instrumento adequado e suficiente para a concretização do princípio da igualdade; com ela, respeitar-se-ia a medida das desigualdades, tratando-se desigualmente aos desiguais, mas a uma razão adequada.

$\mathrm{O}$ argumento é engenhoso, mas não resiste a um confronto com o princípio da capacidade contributiva. Se, ao graduar-se o tributo, este reclama que se leve em consideração a efetiva capacidade econômica tributável dos indivíduos, não subsistirá um argumento que considere isonômica uma exigência tributária graduada à mesma proporção da renda, de indivíduos de rendas distintas.

A proporcionalidade considera isonômico exigir-se os mesmos $20 \%$ de tributo tanto de um contribuinte que ganhe dois salários-mínimos quanto do que perceba cinquenta salários, porque, supostamente, estariam eles realizando o mesmo sacrifício relativo. Entretanto, a toda evidência, sabe-se que o sacrifício realizado pelos dois contribuintes desse exemplo não é equivalente, embora fundado em uma mesma alíquota proporcional. Quanto ao primeiro deles, esta exigência tributária certamente lhe diminuiria a possibilidade de aquisição de bens de primeira necessidade, essenciais; relativamente ao segundo, essa privação representaria diminuição no consumo de bens supérfluos, isto é, não essenciais ${ }^{36}$, e/ou, uma menor capacidade de poupança (considerando que parte desta fração de sua renda, se não lhe fosse tributada, se destinaria ao "não-consumo", isto é, à poupança ${ }^{37}$ ); isto ocorre pois o segundo contribuinte se encontra a um nível de capacidade econômica muito além do necessário ao alcance das

\footnotetext{
${ }^{36} \mathrm{Na}$ literatura econômica, a respeito desse fenômeno diz-se que a "utilidade marginal da renda é decrescente", quer dizer, a utilidade (satisfação, bem estar) que o indivíduo consumidor obtém com acréscimos à sua renda, "na margem", decresce na razão direta do aumento da renda. Intuitivamente, já sabemos que a satisfação proporcionada pelo dinheiro diminui conforme aumenta a renda - um acréscimo de $\mathrm{R} \$ 100$ à renda de uma família paupérrima não lhe proporciona uma satisfação muito maior que se concedido a uma família rica, onde pode até passar despercebido no orçamento?

${ }^{37}$ Ainda no campo do "economês", a propensão marginal a poupar, isto é, o percentual da renda que será poupado, "na margem", aumenta na razão direta do aumento da renda. Isso também nos parece intuitivo - quanto maior a renda do indivíduo, maior sua capacidade de poupança.
} 
"condições mínimas de existência humana digna"38. A proporcionalidade, destarte, impõe graus de sacrifício diferentes aos contribuintes; isto porque trata igualmente a contribuintes desiguais, abstraindo-se da real consideração de suas capacidades econômicas.

A tributação progressiva é, assim, uma espécie de discriminação legítima, ancorada no conteúdo do princípio da igualdade; tal conclusão está autorizada não só pelos ensinamentos dantes expostos de Ricardo Lobo Torres, como pelo teste do método de Celso Antônio Bandeira de Mello ${ }^{39}$, concebido para a análise da legitimidade das diferenciações impostas pelo direito, o qual se pode aplicar à tributação progressiva ${ }^{40}$.

Para o renomado administrativista, a instituição de um tratamento jurídico discriminatório entre cidadãos prescinde do reconhecimento de que cumpre ela com as exigências do conteúdo do princípio da igualdade. A análise desta compatibilidade foi organizada didaticamente pelo doutrinador em três "passos" a serem seguidos pelo intérprete; se o tratamento diferenciado em estudo perpassá-los com êxito, deve ser considerado legítimo.

Em primeiro lugar, no esquema de Bandeira de Mello, deve-se fazer a identificação do elemento tomado como fator de desigualação, isto é, do elemento existente na realidade que servirá de fundamento para a instituição do tratamento jurídico desigual. No caso da tributação progressiva, é a desigualdade de renda e/ou patrimônio entre contribuintes; em outras palavras, o fato de deterem capacidades econômicas diferentes.

Em segundo, tem de haver uma correlação lógica abstrata entre o "fator erigido em critério de discrímen e a disparidade estabelecida no tratamento jurídico diversificado". Neste momento, é "agredida a igualdade quando o fator diferencial adotado para qualificar os atingidos pela regra não guarda relação de pertinência lógica com a inclusão ou exclusão no benefício deferido ou a inserção ou arredamento do gravame

\footnotetext{
${ }^{38}$ TORRES, Ricardo Lobo, Op. cit., p. 438.

${ }^{39}$ O conteúdo jurídico do princípio da igualdade. São Paulo: Revista dos Tribunais.

${ }^{40}$ É o que faz OLIVEIRA, Op. cit., 1988, p. 37.
} 
imposto". Em virtude do exposto em defesa da progressividade, a pertinência lógica entre a tributação progressiva e a existência de capacidades econômicas desiguais fica evidente; para igualar-se o sacrifício realizado por contribuintes de capacidades econômicas diferentes, é necessário que a tributação aumente, progressivamente, na razão direta do aumento da renda.

Por fim, o terceiro passo envolve observar se o tratamento desigual guarda relação lógica com os interesses absorvidos no sistema constitucional. Não basta, assim, que o tratamento jurídico diferenciado seja capaz de tratar a desigualdade material observada; é necessário, também, que esse tratamento encontre fundamento no ordenamento constitucional.

No caso brasileiro, a Constituição admite um sistema de tributação progressiva. A estrutura progressiva tem lastro na cláusula do princípio da capacidade contributiva (Art. $145, \S 1^{\circ}$ ), de forma implícita, bem como em dispositivos alusivos a espécies tributárias em concreto, explicitamente: no Imposto sobre a Renda - Art. $153, \S 2^{\circ}$, I; no Imposto Predial Territorial Rural - Art. 153, $\$ 4^{\circ}$, I; no Imposto Predial Territorial Urbano, Art. 156, $\S 1^{\circ}$, I, e no mesmo Imposto, em caráter extrafiscal (política urbana) - Art. $182, \S 4^{\circ}, I^{41}$.

Em sua obra, Celso Antônio admite que o reconhecimento da legitimidade aos tratamentos discriminatórios não é uma atitude mecânica em face da realidade, sendo condicionada pelo tempo histórico. Parece-nos, assim, coerente a um Estado distributivista, voltado à redução da desigualdade sócio-econômica existente, tributar mais pesadamente os cidadãos, em razão de sua capacidade econômica mais vultosa.

A outra classe de argumentos que se desenvolvem contra a tributação progressiva está no campo da economia. Entretanto mesmo Aliomar Baleeiro, insuspeito conservador, aprovava - embora somente nos ditos

\footnotetext{
${ }^{41}$ Não obstante a inclusão de uma norma geral expressa sobre a progressividade na Constituição possa contribuir para as reformas neste sentido.
} 
tributos "pessoais" argumentos de ordem econômica:

Tribunais estrangeiros já se inclinaram por critérios empíricos, como o de $33 \%$ da renda, adotado pela Corte Suprema da Argentina. Mas esse problema é fundamentalmente econômico. E, à luz da economia, é fácil provar, até com a experiência, que, na tributação progressiva, se poderá atingir até quase $100 \%$ da renda - do que há fartos exemplos - sem destruir a propriedade, impedir o trabalho, desencorajar a iniciativa ou ultrapassar a atividade econômica ${ }^{43}$.

O mesmo autor resume em um parágrafo a ideia central destas críticas; para ele, até meados do século XIX,

impostos progressivos soavam como confisco, rapina, comunismo e subversão social, a despeito dos argumentos lógicos que a favor de seu desenvolvimento desenvolveram alguns nobres espíritos. Mc Culloch comparava o Fisco progressivo aos selvagens que, segundo Montesquieu, abatiam as árvores para colheita dos frutos. Para outros, era o 'abutre a devorar as próprias entranhas' ou o 'roubo graduado' ${ }^{14}$.

Não cabe a esta monografia explicitar exaustivamente as críticas de fundo econômico. Entretanto, aludiremos a elas, com a necessária brevidade, visando contextualizar a defesa e a crítica à tributação progressiva. Para os críticos à progressividade na economia, esta modalidade de tributação impediria a acumulação de capital, o investimento, e, portanto, o desenvolvimento econômico das sociedades. A estrutura progressiva geraria um desestímulo à eficiência, ao "punir" as maiores produtividades - expressas em maiores rendas - com uma tributação proporcionalmente maior. Como na frase de Baleeiro, na busca pelos "frutos", abater-se-ia a própria "árvore": ao minar-se a capacidade de produção, ficaria comprometida a própria arrecadação futura.

No Brasil, espíritos mais avessos à tributação progressiva aproveitam-se de nossa condição peculiar de país "em desenvolvimento" para opor dificuldades adicionais a este instrumento de tributação. Esse argumento parte do mesmo pressuposto antes apresentado - de que o que gera desenvolvimento é existência de capital. Assim, países supostamente carentes de capital como o nosso deveriam tomar como prioridade absoluta

\footnotetext{
${ }^{42}$ BALEEIRO, Aliomar. Op. cit., p. 363. Para um detalhamento do debate sobre a classificação entre tributos reais e pessoais, ver trecho pertinente ao Imposto Predial Territorial Urbano, no Capítulo 3.

${ }^{43}$ BALEEIRO, Aliomar. Op. cit., p. 265.

${ }^{44}$ BALEEIRO, Aliomar. Op. cit., p. 372.
} 
o estímulo à poupança, como a única saída realmente capaz de gerar desenvolvimento econômico. A progressividade seria uma ideia fora do lugar, própria dos países desenvolvidos; inadequada, pois, à nossa realidade. In verbis:

Os países em desenvolvimento devem optar entre o produtivismo e o redistributivismo. O produtivismo, como filosofia econômica, propõe uma primeira fase, na qual haverá concentração de renda. Esta, por sua vez, ensejaria um rápido crescimento econômico e, em seguida, far-se-ia a distribuição de renda. Esta teoria foi proposta tendo em vista dados estatísticos que estabeleciam que a taxa de poupança das classes de maior renda eram mais elevadas que a das outras classes. Ora, como o problema dos países em desenvolvimento, via de regra, é capital, em outros termos, poupança, estaria na concentração de renda a solução do problema. Esta concentração pode ocorrer, seja pela transferência de renda de uma classe para a outra, seja pelo aumento desigual da renda. De acordo com o censo de 1970, houve, no Brasil, uma maior concentração de renda da população, em relação ao censo de 1960, apesar de os pobres terem melhorado o seu poder aquisitivo ${ }^{45}$.

Pedimos licença para contraditar tais críticas. Quanto ao suposto desestímulo ao crescimento econômico, podemos tecer as seguintes considerações: (i) relativamente ao pressuposto da crítica - de que esse crescimento é, necessariamente, algo positivo -, podemos considerar que o mero crescimento econômico, sem mudança estrutural tampouco distribuição de renda, não gera desenvolvimento sócio-econômico. A própria realidade brasileira do crescimento econômico durante a Ditadura Militar - os anos do Milagre Econômico - demonstra o argumento; (ii) há possibilidade de geração de crescimento econômico simultaneamente a um movimento de distribuição da renda e da riqueza. Quanto à tese de que a poupança é a única causa efetiva do investimento, e, portanto, do crescimento econômico, podemos considerar a crítica que lhe faz a doutrina keynesiana, que, diante da experiência da depressão na demanda na década de 1930, passa a considerar que o investimento é resultado, fundamentalmente, do nível das taxas de juros e das expectativas dos empresários quanto ao crescimento da demanda por bens e serviços. Pouco importaria, para tanto, o nível de poupança das sociedades - países como os

\footnotetext{
${ }^{45}$ SIMONSEN, Mário Henrique; CAMPOS, Roberto de Oliveira. A nova economia brasileira,

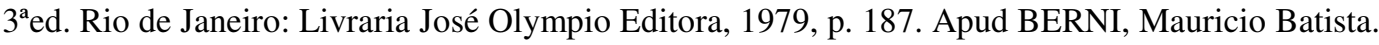
Op. cit., p. 35-36.
} 
Estados Unidos da América, por exemplo, ostentam baixas taxas de poupança convivendo com altos níveis de investimento produtivo. A concentração de renda, assim, ao invés de estimular o desenvolvimento, favoreceria a poupança, e, portanto, o entesouramento; o que acarretaria em uma redução nos investimentos, pois os empresários, diante da compressão no consumo - resultado do excesso de poupança -, deixariam de investir. Por fim, contrariamente ao que a crítica a progressividade afirma, essa estrutura de tributação não engessa a progressividade; países capitalistas avançados como a França e os mesmos EUA já ostentaram em determinados momentos de sua história alíquotas máximas de até $100 \%$, sem prejuízo para o estímulo à produtividade e à inovação. Remetemos, a este respeito, à tabela do Anexo II, que compara as faixas de Imposto sobre a Renda em vigor em diferentes países, muitas delas com alíquotas bem maiores que as praticadas no Brasil e com um número maior de faixas ${ }^{46}$.

Diante do exposto, vê-se que a defesa da progressividade está relacionada à reabilitação e à concretização do conteúdo do princípio da capacidade contributiva. Um sistema tributário, parece-nos, será tão mais verdadeiramente progressivo quanto mais atento à consideração da diversidade entre as capacidades econômicas dos contribuintes. Fácil perceber, assim, que um sistema tributário regressivo representa a antítese do princípio da capacidade contributiva, e, portanto, da igualdade.

Fica clara, também, a relação entre um Estado distributivista como se propõe o brasileiro, declaradamente voltado à redução da desigualdade sócio-econômica, e o princípio da capacidade contributiva. Tanto mais se atente para o sentido remediador da realidade desigual inerente ao princípio da igualdade, mais se tenderá a uma estrutura progressiva da tributação, eis que a mais vocacionada a concretizar o real conteúdo do princípio aqui estudado.

\footnotetext{
46 Para um detalhamento da discussão sobre o Imposto de Renda, ver o trecho pertinente no Capítulo 3.
} 
Nesse processo de redução da desigualdade econômica, promovido pela tributação progressiva, não se pode cogitar de qualquer suposta "neutralidade" do sistema tributário. Esse mito, elaborado no âmbito da ciência das finanças, reza que à tributação não caberia influir na distribuição dos recursos econômicos na sociedade. Ora, toda sociedade é dotada de características econômicas e sociais que não só influenciam o sistema tributário vigente, como são por ele influenciadas. Ao tributar a sociedade, o Estado atua sobre as forças do mercado, pois retira, transfere e distribui renda, conforme os objetivos socialmente desejados; essa influência recíproca ${ }^{47}$ existente entre uma sociedade e seu sistema tributário desmente o postulado da "neutralidade". Os objetivos desejados, já explicitados, no caso de nossa República é o da redução da desigualdade econômica.

Nem mesmo a tributação proporcional, considerada por muito tempo o paradigma da tributação justa, é "neutra". Ao não procurar promover a distribuição da renda, a proporcionalidade, muito além de supostamente neutra, é "injusta em razão de não contribuir para a reversão do perverso quadro social",48.

\footnotetext{
${ }^{47}$ Sobre esse ponto, BALEEIRO, Aliomar. Op. cit., p. 309.

${ }^{48}$ HETZEL, Moacir. Op. cit., p. 106; de acordo, BERNI, Mauricio Batista. A capacidade contributiva e a concentração de rendas. Rio de Janeiro. 1982. Dissertação (mestrado). Departamento de Ciências Jurídicas da PUC-Rio, p. 65.
} 


\section{Um estudo do sistema tributário no Brasil: capacidade contributiva e progressividade}

\subsection{Implicações do princípio da capacidade contributiva para a política tributária}

Já definimos o princípio da capacidade contributiva; mas isso não é suficiente para analisarmos a legitimidade de um dado sistema tributário, considerado em especial o postulado da progressividade; antes de estudarmos o sistema tributário brasileiro em particular, portanto, algumas observações sobre as implicações do princípio para uma boa política tributária se fazem necessárias.

Em primeiro lugar, verificar se um dado sistema tributário respeita o princípio da capacidade contributiva exige considerar, na política tributária, uma análise global da tributação exigida da pessoa do contribuinte. Com isso, será necessário mensurar todos os tributos exigidos, e não somente um ou alguns deles:

Esse sacrifício, essa privação parcial de valores, transformada em contribuição compulsória, deve ser aquilatada sob o seu aspecto global e nunca em relação a cada imposto isoladamente, ou melhor, os diferentes impostos integrantes do sistema ${ }^{49}$.

Essa perspectiva global está relacionada, também, a segunda lição importante para a política tributária: uma abordagem interdisciplinar do fenômeno da tributação, pois a privação financeira global que sofre o contribuinte, em virtude da tributação, deve ser preferencialmente analisada por meio do arsenal que oferecem as ciências econômicas e a ciência das finanças. Como desvendar, por exemplo, o quantum global exigido de um determinado contribuinte, sem considerar o fenômeno da chamada repercussão, presente nos tributos indiretos (aqueles "devidos, de direito, por uma pessoa, - o 'contribuinte de direito' - mas suportados por outra $o$ 'contribuinte de fato ${ }^{\prime, 50}$ ). O tributo indireto, desde que integralmente transferido, não se soma ao quantum global exigido do contribuinte de direito, mas sim de outrem, o contribuinte de fato. Por esse motivo é que,

\footnotetext{
${ }^{49}$ MACHADO, Orvácio Lyra. A concentração da renda e o sistema tributário nacional. Rio de Janeiro. 1979. Dissertação (Mestrado) - Departamento de Ciências Jurídicas da PUC-Rio, p. 26.

${ }^{50}$ AMARO, Luciano. Direito tributário brasileiro, $14^{\mathrm{a}}$ ed. São Paulo: Saraiva, 2008, p. 90.
} 
quando incidente sobre bens e serviços de consumo de massa, acaba por assumir um caráter regressivo, uma vez que contribuintes de capacidade econômicas diferentes arcam com o mesmo quantum de tributo; desse modo, o tributo cobrado compromete uma parcela maior da renda do contribuinte "de fato" a medida que sua renda diminui, o que caracteriza a regressividade.

E, mesmo quando suportados, ao menos em parte, por seus contribuintes de direito, os tributos que, em regra, assumem o caráter de indiretos - notadamente, aqueles incidentes sobre as atividades de produção e circulação de bens e serviços - seguem regressivos em relação às empresas. Isso ocorre pois o tributo indireto "incide igualmente sobre pequenos e grandes empresários, o que provoca uma menor competitividade daqueles em relação a estes em razão de suas diferentes estruturas de custos"

Por fim, o caráter regressivo dos tributos indiretos se acentua em virtude de recaírem eles mais pesadamente sobre bens do que sobre serviços. E justamente os bens têm participação mais significativa na estrutura de consumo das classes mais pobres, que consomem, em geral, proporcionalmente menos serviços que os ricos.

Veja-se, assim, que a abordagem global e interdisciplinar da tributação visa a contornar uma visão frequente no campo do direito, mais atenta aos particularismos das espécies tributárias e à literalidade sonora das leis que à efetiva privação financeira sofrida pelos contribuintes. Sob a influência dessa perspectiva estreita chegou-se a até a rejeitar a classificação entre tributos diretos e indiretos, pelo fato ser "meramente" econômica, e, com isto, irrelevante para o direito ${ }^{52}$. Hoje, contudo, já é pacificamente aceita ${ }^{53}$. Luciano Amaro comenta a respeito dessa relação entre o direito tributário e a ciência das finanças:

\footnotetext{
${ }^{51}$ MOACIR, Hetzel. Op. cit., p. 112.

52 OLIVEIRA, José Domingues de. Op. cit., 1988, p. 22-23.

${ }^{53}$ Reconhecer a importância jurídica da classificação econômica entre tributos diretos e indiretos não implica em abandonar a necessária cautela para com qualquer classificação, e com essa não é diferente: "É preciso ter cautela com essa rotulagem. (...) Essa classificação é fonte de incertezas,
} 
É evidente que os critérios hábeis para uma classificação jurídica dos tributos devem apoiar-se em dados juridicamente significativos, isto é, dados que tenham uma expressão jurídica. Ocorre que a realidade jurídica desses aspectos frequentemente espelha dados que tiveram, antes, uma expressão financeira, pré-jurídica. É, aliás, natural que haja essa correspondência, pois o legislador trabalha com modelos jurídicos que devem ter o mínimo de referibilidade prática, no mundo fenomênico. (...)

Não é por mera coincidência que os critérios invocados pela doutrina, para classificar as espécies tributárias, correspondem aos mesmos dados que, no plano pré-jurídico, foram trabalhados pelos financistas e que, no plano normativo, foram acolhidos pelo ordenamento jurídico quando este cuidou de definir o contorno das espécies tributárias ${ }^{54}$ (grifo nosso).

Uma análise do cumprimento do princípio da capacidade contributiva exige, igualmente, atenção a um terceiro aspecto - aquilatar a soma dos tributos efetivamente exigidos. Em outras palavras, sendo reduzido por qualquer meio legal o quantum devido, via instrumentos diversos como deduções, isenções ou anistias, este resultado líquido é que se deve levar em consideração. Isto evita distorções como as observadas, por exemplo, no sistema de Imposto sobre a Renda no Brasil, que adota a progressividade por faixas; a alíquota efetivamente exigida de contribuintes de renda mais elevada acaba sendo menor que a alíquota em vigor formalmente, em função das maiores oportunidades de dedução e descontos, que, em regra, crescem na razão direta do aumento da renda.

Com tudo quanto se expôs, o princípio da capacidade contributiva incide, necessariamente, sobre um sistema tributário, de uma forma geral, e sobre a tributação global exigida de cada cidadão, em particular. Quanto à tributação exigida de cada cidadão, exige-se, em síntese, (i) analisar a soma global exigida do contribuinte; (ii) considerando a interdisciplinaridade do fenômeno da tributação, (iii) atentando para a soma líquida efetivamente exigida do contribuinte (consideradas todas suas formas de redução deduções, isenções, etc.).

É preciso rejeitar, assim, na política tributária, qualquer alegação de "reserva do possível", que possa ser oposta à plena vigência da capacidade

pois não raras vezes tributos ditos 'indiretos' não são repassados a terceiros, mas suportados pelo próprio contribuinte de direito. Por outro lado, é difícil encontrar um tributo dito 'direto' que não possa, por algum mecanismo, ser 'embutido' no preço de bens e serviços, e, portanto, repassado a terceiros”. AMARO, Luciano. Op. cit., p. 90.

${ }^{54}$ AMARO, Luciano. Op. cit., p. 74. 
contributiva, em virtude da má-colocação da locução "sempre que possível" no início do período contido pelo Art. $145, \S 1^{\circ}$ da $\mathrm{CF} / 88$; a locução restritiva em questão remete, como pudemos expor, tão somente ao subprincípio da personalização.

Entretanto, evidentemente que, diante das espécies tributárias em concreto, esse preceito não pode conduzir a um padrão unívoco e definitivo de tributação; o papel de uma boa política tributária, portanto, é justamente o de realizar essa "sintonia fina", compatibilizando, graduando e sopesando as diferentes espécies tributárias entre si, para que a soma tributária líquida efetivamente exigida de qualquer indivíduo, bem como o sistema tributário de uma forma geral, não violente o princípio da capacidade contributiva.

Portanto, na casuística da política tributária, diante de tributos em concreto, aplicam-se os subprincípios da personalização, proporcionalidade, progressividade e seletividade conforme permita a estrutura do tributo em questão, em face de considerações sobre a possibilidade prática e técnica.

Para ilustrar a observação, tome-se o caso de um tributo sobre a circulação de mercadorias, beira a impossibilidade prática que este seja progressivo em relação ao capital da empresa, por exemplo. Tampouco faz sentido falar em seletividade na tributação direta sobre a propriedade. É isto que quer dizer Ricardo Lobo Torres quando afirma que a capacidade contributiva "submete-se à possibilidade técnica de a base imponível suportar a alíquota proporcional, progressiva, seletiva ou personalizada" $" 55$. No mesmo sentido, temos Aliomar Baleeiro ${ }^{56}$.

Em verdade, note-se, não é a aplicabilidade do princípio da capacidade contributiva que está em jogo, mas a de seus subprincípios, que incidirão ou não sobre uma espécie tributária em particular, conforme as determinações da política tributária. As observações sobre as implicações do princípio da capacidade contributiva para o sistema tributário, de uma forma geral, e para cada contribuinte em particular (em que se recomenda

\footnotetext{
${ }^{55}$ TORRES, Ricardo Lobo. Op. cit., p. 435.

${ }^{56}$ BALEEIRO, Aliomar. Op. cit., p. 308.
} 
atenção à exigência tributária global líquida e efetiva), portanto, seguem pertinentes.

Por fim, é necessário considerar o campo da chamada extrafiscalidade, para o qual a tributação não visa diretamente à arrecadação, mas a qualquer outra finalidade ${ }^{57}$; ficam abrangidas, portanto, coisas tão díspares entre si quanto a política de saúde e a política fundiária. É nesse âmbito que o princípio da capacidade contributiva pode sofrer, per se, constrição, por força da necessária compatibilização com as demais normas constitucionais, necessária diante de determinados casos concretos, o que, de certa forma, foge ao escopo desta monografia, que não pretende debater esta resolução de casos concretos.

Diante de um conflito aparente, em um caso concreto, entre o princípio da capacidade contributiva e alguma outra norma de caráter extrafiscal, pode prevalecer a norma extrafiscal, desde que esta tenha assento constitucional. A título de exemplo, suponhamos que, por força de uma nova política de saúde, mais agressiva, o governo passe a tributar pesadamente o consumo de cigarro. A situação de um indigente que não consiga largar o vício, e, para mantê-lo, comprometa a própria subsistência, pode não violar a capacidade contributiva. O que ocorre é que esse princípio cederia passo ao de proteção à saúde. Reiteramos, por fim, que só se pode suspender a aplicação do princípio da capacidade contributiva diante de tributos em concreto, e sob o influxo de um objetivo extrafiscal válido.

Mas há ainda, por trás da efetivação, na política tributária, do subprincípio da progressividade e, especialmente, da personalização, um problema empírico fundamental. É imprescindível, para um sistema tributário progressivo e personalizado, uma administração tributária adequada; para Aliomar Baleeiro ${ }^{58}$, um sistema tributário que funcione segundo esses postulados pressupõe uma máquina arrecadatória eficaz. Essa

\footnotetext{
${ }^{57}$ OLIVEIRA, José Domingues de. Op. cit., 1988, p. 54.

${ }^{58}$ Op. cit., p. 308.
} 
necessidade pode levantar indagações acerca da exequibilidade ou viabilidade política que escapam, igualmente, ao escopo desta monografia.

Findas as considerações de ordem geral sobre as implicações do princípio da capacidade contributiva para uma boa política tributária, podemos passar ao estudo do caso particular do sistema tributário brasileiro, para verificar, à luz das lições expostas, sua adequação ao princípio da capacidade contributiva, e sua legitimidade face à diretriz constitucional distributivista.

\subsection{Estudo do sistema tributário do Brasil}

Neste tópico, queremos indagar sobre a adequação do sistema tributário brasileiro à capacidade contributiva e, em especial, à progressividade. Para tanto, empreenderemos um estudo, embora seletivo e não exaustivo, do sistema tributário em nosso país. É relevante, aqui, ter em consideração, na análise das características fundamentais de nosso sistema, as considerações expostas anteriormente sobre as implicações deste princípio angular da tributação para uma boa política tributária, atentando especialmente para o fenômeno da repercussão tributária (típico dos tributos indiretos) e para os diversos modos de redução do quantum de tributos devido ao Estado (notáveis, por exemplo, no Imposto sobre a Renda).

Diante desse objetivo, não podemos deixar de registrar, preliminarmente, a característica mais impressionante do sistema tributário brasileiro: sua acentuada regressividade; a qual pode ser tida por uma verdadeira antítese do princípio da capacidade contributiva, e, portanto, da igualdade. Veja-se, a este respeito, a seguinte tabela, divulgada em estudo do Instituto de Pesquisa Econômica Aplicada em Junho de 2009:

\begin{tabular}{lr}
\multicolumn{2}{r}{ Tabela 1. Distribuicão da Carga Tributária Bruta } \\
\multicolumn{2}{c}{ segundo faixa de salário mínimo } \\
Renda Mensal Familiar & Carga Tributária Bruta \\
(em \% da Renda) - 2008 \\
Até 2 SM & 53,9 \\
2 a 3 & 41,9
\end{tabular}

\footnotetext{
59 Instituto de Pesquisa Econômica Aplicada (IPEA). Comunicado da Presidência $n^{o}$. 22. Disponível em <http://www.ipea.gov.br/sites/000/2/comunicado_presidencia/09_06_30_ComunicaPresi_22_Rece itaPublica.pdf $>$. Acesso em 20.09.2009, tabela 1 (adaptada).
} 
Nota-se que a estrutura tributária brasileira sequer é proporcional: enquanto uma família com renda de até 2 salários mínimos paga, em média, $53,9 \%$ em tributo, uma outra que receba mais de 30 salários entrega apenas $29 \%$ de sua renda. No Anexo I desta monografia, elaboramos um gráfico, com base nos dados da tabela, em que se pode visualizar com clareza este caráter regressivo; a curva gerada é descendente, o que expressa uma relação inversa entre as faixas de renda e a carga tributária incidente em cada uma delas. Com isso, as camadas mais pobres da sociedade contribuem com uma parcela de sua renda proporcionalmente superior à parcela tributada dos mais ricos.

Assim, pode-se dizer que a desigualdade socioeconômica existente na sociedade é reforçada pelo sistema tributário. Essa situação violadora do princípio da capacidade contributiva é tributária do sistema tributário gestado durante a Ditadura Militar. Antes das reformas da década de 1960, o sistema tributário via-se permeado de superposições, incoerências e $\operatorname{lacunas}^{60}$, descompassado em relação à realidade econômica do país ${ }^{61}$. Nesse contexto, o Golpe de 1964 viabilizou politicamente a realização de uma profunda reforma tributária, que procurou promover coerência e organicidade ao sistema.

Tais reformas foram efetuadas, principalmente, por meio da Emenda à Constituição de 1946 de n. ${ }^{\circ}$ 8/1965 (incorporada, com poucas inovações à Carta de 67 e à E.C. n. ${ }^{\circ}$ 1/1969) e do Código Tributário Nacional (Lei n. ${ }^{\circ}$ 5.172/1966); e estiveram voltadas, expressa e declaradamente, à concentração da renda e da riqueza no país, subsidiariamente a um processo de desenvolvimento nacional. Nessa concepção, o sistema tributário teria a

\footnotetext{
${ }^{60}$ BERNI, Mauricio Batista. Op. cit., p. 32-33.

${ }^{61}$ HETZEL, Moacir. Op. cit., p. 22.
} 
função precípua de estimular a geração de poupança, reputada fundamental à formação de capital para o desenvolvimento ${ }^{62}$.

Entre as características do sistema tributário então construído, relevantes para os fins desta monografia, apontamos as seguintes:

a) O Imposto sobre a Renda era marcado pela concessão de diversos incentivos fiscais - na forma de deduções, abatimentos e isenções - que beneficiavam sobremaneira os mais ricos, já que essas oportunidades aumentavam na medida em que crescia a renda;

b) A regressividade da estrutura tributária do Imposto sobre a Renda, em vigor a despeito do discurso oficial, que, formalmente, adotava a progressividade. A exemplo disso, temos que, em 1974, por exemplo, tributavam-se os rendimentos do trabalho em $35,3 \%$ e os ganhos de capital, em $0,03 \%{ }^{63}$;

c) A participação acentuada dos tributos sobre produtos na arrecadação tem origem, também, nesse momento; essa modalidade é a que mais se presta ao fenômeno da repercussão tributária (tributo indireto);

d) Ampla sonegação pelos contribuintes, o que também acaba tendo um efeito concentrador, já que as oportunidades para sonegar são maiores nos segmentos de maior renda.

O sistema tributário criado durante a Ditadura Militar não foi significativamente alterado pela CF-88, não obstante seus louváveis avanços na direção de um sistema mais conforme ao princípio da capacidade contributiva. Mesmo a lei complementar exigida pela Constituição para dispor sobre normas gerais e regras de resolução de conflitos federativos até hoje não foi editada, motivo pelo qual subsiste, ainda, o diploma anterior - o Código Tributário Nacional -, com status de

\footnotetext{
${ }^{62}$ Conforme tivemos oportunidade de expor ao final do Capítulo 2.

${ }^{63}$ HETZEL, Moacir. Op. cit., p. 39.
} 
lei complementar. Não obstante, entre os avanços estão a retomada expressa do princípio da capacidade contributiva no sistema, e a menção ao postulado da progressividade em dispositivos específicos.

O sistema tributário permaneceu, pois, regressivo. Ao fim e ao cabo, ele é feito do emaranhado dos tributos que o compõem, sendo o processo de "densificação" dos princípios - a concretização de seu conteúdo por meio da edição de regras imediatamente aplicáveis - inevitavelmente lento. Nos dias atuais, por conseguinte, permanece um padrão regressivo no sistema tributário nacional.

Hoje se pode atribuir o padrão de incidência regressiva da tributação, fundamentalmente, às seguintes características do sistema: grande participação dos tributos sobre produtos na arrecadação; reduzida participação dos tributos diretos sobre a renda, patrimônio, riqueza ou capital na arrecadação; estrutura inadequada dos tributos sobre a renda, propriedade ou capital.

Essa estrutura é inadequada, quanto ao imposto de renda, por ser brandamente progressiva, tendendo à regressividade em determinadas situações; quanto aos tributos diretos sobre o patrimônio, a despeito da autorização constitucional hoje existente, permanece um caráter geral regressivo ou proporcional somente.

Em seguida analisaremos cada uma dessas características.

\subsubsection{Grande participação dos tributos sobre produtos na arrecadação total}

Por tributos sobre produtos entendemos aqueles incidentes sobre atividades de produção, circulação ou consumo de bens ou serviços - a categoria denominada "impostos sobre produtos" nas Contas Nacionais, pelo Instituto Brasileiro de Geografia e Estatística (IBGE); ficam abrangidas nessa modalidade as mais diversas espécies tributárias, de contribuições a impostos. Entre as mais relevantes, destacamos - em ordem 
decrescente de $\operatorname{arrecadação~}^{64}$ : o Imposto sobre Circulação de Mercadorias e Serviços (ICMS), a Contribuição para o Financiamento da Seguridade Social (Cofins), o Imposto sobre Produtos Industrializados (IPI); o Imposto sobre Serviços (ISS); o Imposto sobre Importações; a Contribuição de Intervenção no Domínio Econômico incidente sobre as operações realizadas com combustíveis (CIDE-Combustíveis); e o Imposto sobre Operações Financeiras (IOF).

Importante notar que nesses tributos ocorre o fenômeno da repercussão tributária, que dá origem à chamada incidência indireta. Muito embora a incidência efetiva de qualquer tributo dependa "da capacidade ou não de as firmas repassarem esse tributo aos consumidores" ${ }^{\prime 65}$, como, em regra, esses tributos incidem sobre atos negociais praticados por pessoas jurídicas,

o valor do imposto pago antecipadamente por uma empresa é recuperado, em geral, pela incorporação do custo tributário ao preço negociado nas transações com terceiros. Se o terceiro também é uma pessoa jurídica, o processo de transferência de custo se repete de tal sorte que assumirá o ônus tributário o consumidor final do bem ou serviço transacionado. Praticamente todos os impostos pagos pelas empresas, sejam sobre a venda de mercadorias, folha de pagamentos, ativos, etc., são, integral ou parcialmente, agregados ao preço e suportados por quem dá o destino final ao produto/serviço ${ }^{66}$.

O resultado dessa transferência do ônus ao consumidor final nos tributos sobre produtos é que eles acabam assumindo um padrão regressivo em relação à renda das famílias, como se pode depreender da análise do gráfico:

\section{Gráfico 1. Carga Tributária Indireta}

\footnotetext{
${ }^{64}$ Instituto de Pesquisa Econômica Aplicada (IPEA). Cláudio H. dos Santos et. al. A evolução da Carga Tributária Bruta Brasileira no período 1995-2007: tamanho, composição e especificações econométricas agregadas (texto para discussão). Brasília, 2008. Disponível em http://www.ipea.gov.br/sites/000/2/pdf/CT_3_4_2008_TD_Final.pdf>. Acesso em 10/11/2009,p. 3-4.

65 HINDRINKS, J.; MILES, G. Intermediate Public Economics. Louvain La Neuve, 2004. Mimeografado, seção 11.5. Apud IPEA. Cláudio H. dos Santos et. al. Op. cit., p. 13.

66 Secretaria da Receita Federal. Estudo Tributário $N^{o}$ 04: A Progressividade no Consumo Tributação Cumulativa e sobre o Valor Agregado. Brasília, 2002. Disponível em $<$ http://www.receita.gov.br/Publico/estudotributarios/estatisticas/16\%20Progressividade\%20no\%2 0Consumo.pdf>. Acesso em 10/11/2009, p. 7.
} 
por faixa de renda (décimos da renda): 2002-2003 ${ }^{67}$

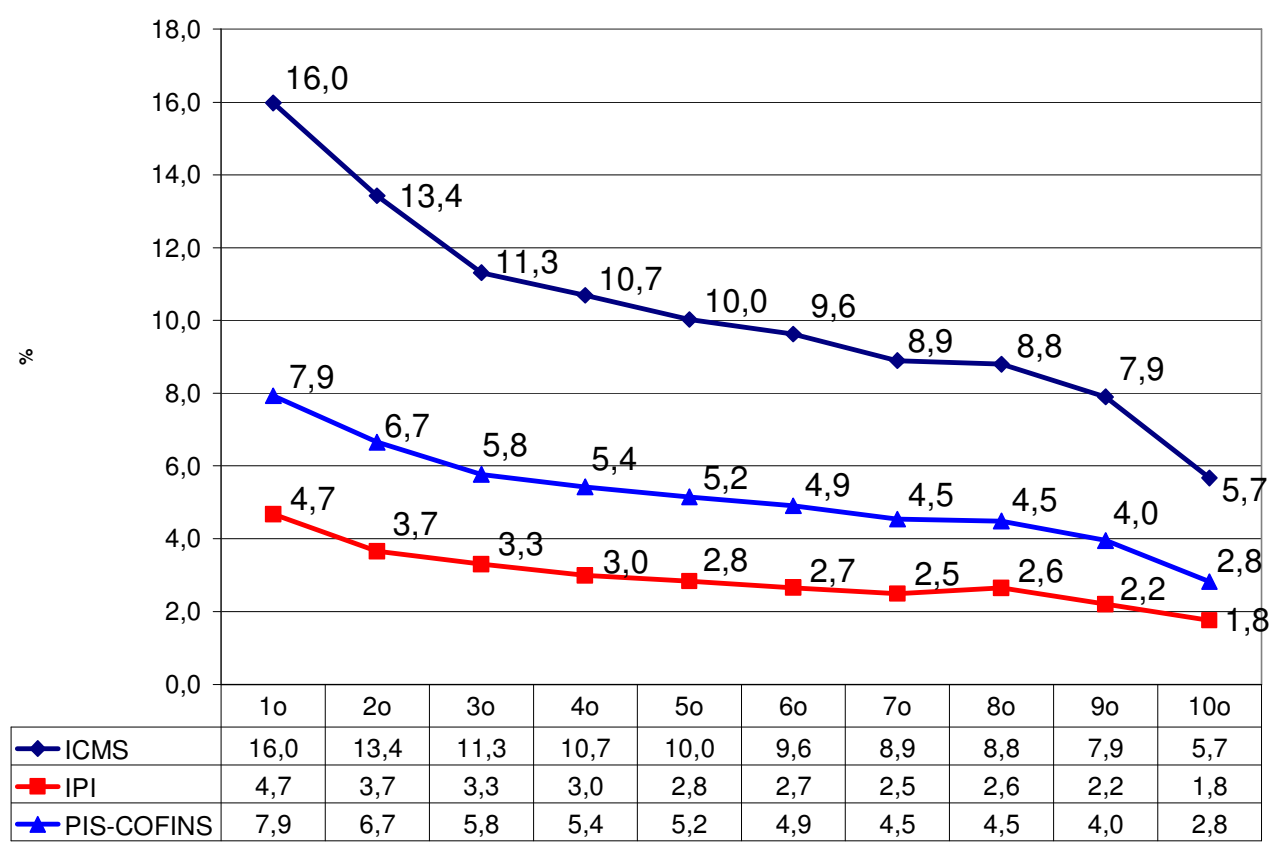

O caráter regressivo - a incidência do tributo em proporção à renda diminuindo na medida em que a renda das famílias aumenta - fica evidenciado nos três tributos mais importantes sobre produtos - ICMS, IPI e PIS-COFINS. A regressividade mais suave do Imposto sobre Produtos Industriais reflete, provavelmente, os esforços mais intensos realizados para adequar essa espécie tributária ao princípio da seletividade, através da desoneração de produtos essenciais de consumo de massa. A própria Constituição é peremptória ao obrigar a União, ao instituí-lo, à observação do princípio, em seu art. $153, \S 3^{\circ}$, I. O ICMS, ao contrário, submetido à disciplina discrepante nos diversos Estados federados, é mais radicalmente regressivo (a inclinação da curva é maior); a própria Constituição, no Art. $155, \S 2^{\circ}$, III, reconhece que a atenção à seletividade, embora recomendável, não é mandatória.

O padrão regressivo dos tributos sobre produtos, conjugado ao seu grande peso na arrecadação, contribui em grande medida para a

\footnotetext{
${ }^{67}$ Instituto de Pesquisa Econômica Aplicada (IPEA). Justiça Tributária. Brasília, 2008. Disponível em <http://www.ipea.gov.br/sites/000/2/pdf/08_06_05_JusticaTributaria.ppt>. Acesso em 28.09.2009, Slide $\mathrm{n}^{\circ}$. 30. No eixo $x$ (horizontal), a renda é divida em "décimos da renda"; cada faixa corresponde a $10 \%$ das famílias brasileiras, desde o décimo mais pobre ( $1^{\text {a }}$ faixa) até o décimo mais rico ( $10^{\mathrm{a}}$ faixa).
} 
regressividade geral do sistema tributário. Em 2007, por exemplo, os tributos sobre produtos representavam impressionantes 40,5\% da Carga Tributária Bruta ${ }^{68}$; a cifra é alta, mas há um avanço importante, se considerarmos que em 1991 mais de $70 \%$ da arrecadação era originada desses mesmos tributos ${ }^{69}$.

\subsubsection{Reduzida participação dos tributos sobre a renda, propriedade ou capital na arrecadação total}

Os tributos sobre a renda, patrimônio ou capital eram responsáveis por $29 \%$ da Carga Tributária Bruta em $2007^{70}$. Comparando este patamar aos $40,5 \%$ dos tributos sobre produtos, tem-se uma ideia clara sobre as razões da regressividade de nosso sistema tributário.

Entre os tributos mais importantes dessa categoria, que foram responsáveis, entre 2000 e 2005, pela cifra média de $98 \%$ da arrecadação, estão os seguintes, incidentes sobre a renda ou a propriedade ${ }^{71}$ : o Imposto sobre a Renda (IR), o Imposto sobre Veículos Automotores (IPVA), o Imposto sobre a Propriedade Predial e Territorial Urbana (IPTU), a Contribuição Provisória sobre Movimentação Financeira (CPMF) (já revogada) e a Contribuição sobre o Lucro Líquido de Pessoas Jurídicas (CSLL); não há, na lista dos mais expressivos, sequer um tributo sobre o capital.

Os tributos sobre a propriedade, renda e capital provocam, em geral, incidência direta, quer dizer, o contribuinte dificilmente repassa o ônus tributário a terceiros. Seu peso na arrecadação é muito baixo, se comparado ao patamar adequado a uma estrutura verdadeiramente progressiva. Os avanços ficam por conta do recente aumento desse peso - passaram de um peso de $21,1 \%$ na arrecadação, em 1995 , para os $29 \%$ de 2007 ; conjugada a uma redução na participação dos tributos sobre produtos, no mesmo

\footnotetext{
${ }^{68}$ IPEA. Cláudio H. dos Santos et. al.. Op. cit., p. 3; IPEA. Justiça Tributária (op. cit.), slide nº 22.

${ }^{69}$ HETZEL, Moacir. Op. cit., p. 41.

${ }^{70}$ IPEA, Justiça Tributária (op. cit.), slide $\mathrm{n}^{\circ} .22$.

${ }^{71}$ IPEA. Cláudio H. dos Santos et. al. Op. cit., p. 6.
} 
período, de $46,41 \%$ para $40,5 \%$, como se pode observar da comparação entre os gráficos:

Gráficos 2 e 3: Composição da arrecadação no país:

\section{Comparação entre 1995 e $2007^{72}$}

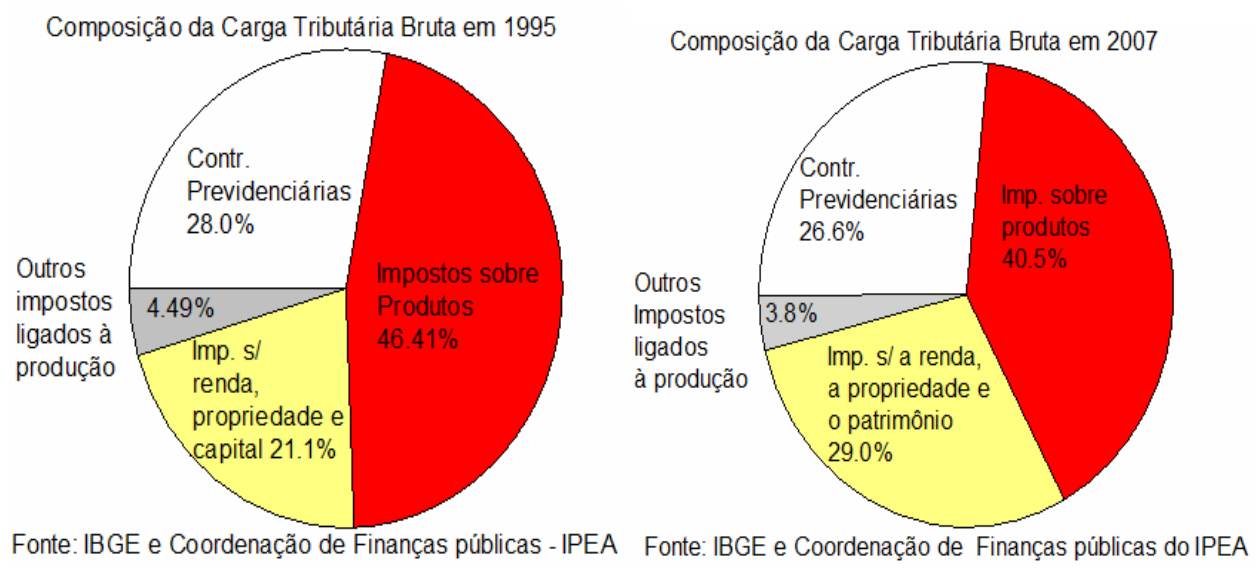

Entre as medidas compatíveis com um aumento mais substancial do peso desses tributos diretos na arrecadação, estaria, certamente, um incremento na arrecadação do Imposto Territorial Rural, hoje de arrecadação inexpressiva, apesar do elevado grau de concentração da propriedade fundiária no país, e de sua estrutura formalmente progressiva.

Outra medida digna de nota seria uma utilização mais ostensiva da contribuição de melhoria. O tributo, devido pelo proprietário em virtude de valorização causada em seu bem imóvel pela realização de uma obra pública, constituiria um excelente meio para os governos financiarem, de forma legítima, o desenvolvimento da infra-estrutura do país, pois podem ser instituídos, tal como as taxas, pelos três entes federados ${ }^{73}$.

\footnotetext{
${ }^{72}$ IPEA. Justiça Tributária (op. cit.), slide $\mathrm{n}^{\circ}$. 22. As contribuições previdenciárias podem ser divididas, grosso modo, em "a) contribuições de patrões e empregados para o Instituto Nacional do Seguro Social (INSS); b) contribuiç̃̃es para o Programa de Integração Social e o Programa de Formação do Patrimônio do Servidor Público (PIS-PASEP); c) contribuições para o Fundo de Garantia por Tempo de Serviço (FGTS); e d) contribuições para a aposentadoria dos funcionários públicos (pagas pelos próprios e pelo governo)" (IPEA, Cláudio H. dos Santos et. al. Op. cit., p. 8).

${ }^{73}$ Inviabilizando uma utilização mais ostensiva da contribuição, tem-se o Decreto n. ${ }^{\circ}$ 195/1967, que estabelece uma série de requisitos limitadores, além do próprio Código Tributário Nacional, que, em seu art. 82, exige procedimento contraditório prévio para instituição do tributo.
} 
Por fim, registre-se o Imposto sobre Grandes Fortunas, tributo sobre o capital por excelência - modalidade rara - que carece de regulamentação desde a promulgação da Constituição de 1988.

A baixa expressão dos tributos diretos sobre o patrimônio na arrecadação está ligada, evidentemente, à estrutura que vigora nesses tributos, se regressiva, proporcional ou progressiva. Esse elemento tem, evidentemente, importância no reforço à regressividade geral do sistema; uma estrutura, se predominantemente regressiva ou apenas proporcional, indicará um sistema tributário contrário à diretriz constitucional distributivista, e refratário a uma efetiva concretização do princípio da capacidade contributiva.

\subsubsection{Estrutura dos tributos sobre renda, a propriedade e o capital}

Nesta seção, optamos por analisar a estrutura de incidência formal de quatro espécies tributárias: o Imposto Predial Territorial Urbano (IPTU), Imposto de Transmissão de Bens Móveis e Imóveis por Causa Mortis ou Doação (ITCMD), o Imposto Territorial Rural (ITR) e Imposto sobre a Renda (IR). Como se poderá demonstrar, ainda que porventura superados os óbices judiciais e legais à existência de uma estrutura progressiva, esta viabilidade jurídica não garante sua efetivação. Permanece, com isso, um padrão geral proporcional nesta modalidade de tributos, com uma progressividade apenas marginal.

\subsubsection{Imposto Predial Territorial Urbano}

Hoje, por determinação constitucional, pode ser progressivo (Art. 156, $\left.\S^{\circ}, I\right)$. Segue, contudo, sendo uma mera faculdade dos Municípios, a quem cabe instituí-los, o que, evidentemente, compromete a eficácia do dispositivo constitucional - um Município pode, portanto, adotar uma estrutura proporcional na lei regulamentadora.

Antes da Emenda 29/2000, que alterou o dispositivo citado, vigia a orientação adotada pelo Supremo Tribunal Federal no R.E. nº ${ }^{\circ}$ 153771- 
0/MG, consagrada inclusive em Súmula ${ }^{74}$. No acórdão, da lavra do Ministro Moreira Alves, reputou-se inconstitucional, incider tantum, a estrutura progressiva prevista para o IPTU no Município de Belo Horizonte; sob o pálido argumento de que o texto constitucional não permitia a progressividade nos tributos ditos "reais"75, embora, originariamente, o texto constitucional já assim previsse, além da cláusula geral da capacidade contributiva:

Art. 156. Compete aos Municípios instituir impostos sobre: I propriedade predial e territorial urbana; (...) $\S 1^{\circ}$ - O imposto previsto no inciso I poderá ser progressivo, nos termos de lei municipal, de forma a assegurar o cumprimento da função social da propriedade.

A locução "de forma a assegurar o cumprimento da função social da propriedade" foi interpretada restritivamente como alusiva, embora o texto constitucional não o dissesse, à progressividade extra-fiscal da política urbana, prevista no art. $182, \S 4^{\text {o }}$ :

É facultado ao Poder Público municipal, mediante lei específica para área incluída no plano diretor, exigir, nos termos da lei federal, do proprietário do solo urbano não edificado, subutilizado ou não utilizado, que promova seu adequado aproveitamento, sob pena, sucessivamente, de: (...) II imposto sobre a propriedade predial e territorial urbana progressivo no tempo.

Proibiu-se, assim, a progressividade no IPTU, a despeito de expressa autorização já contida no texto original, já que a restrita progressividadesanção prevista para a política urbana submete-se a uma série de exigências limitadoras $^{76}$. Além disso, não toma por base o valor do imóvel, só incidindo no decorrer do tempo, desde que permaneça o comportamento ilícito do proprietário; ao contrário da progressividade fiscal segundo o valor do imóvel, que não tem qualquer caráter sancionatório. Diante disso foi preciso alterar a Constituição para fazê-la cumprir. A E.C. 29/2000 conferiu afirmação categórica ao dispositivo: “Art. 156. $\$ 1^{\circ}$ Sem prejuizo

\footnotetext{
${ }^{74}$ STF. Súmula 668: É inconstitucional a lei municipal que tenha estabelecido, antes da emenda constitucional 29/2000, alíquotas progressivas para o IPTU, salvo se destinada a assegurar o cumprimento da função social da propriedade urbana.

${ }^{75}$ A classificação reza que os tributos reais gravam a propriedade de um bem; enquanto os tributos pessoais incidiriam sobre a pessoa. Como se verá mais adiante, a classificação não presta, senão para fins eminentemente didáticos.

${ }^{76}$ Como a edição de lei federal regulamentadora (o Estatuto das Cidades, Lei $n^{\circ}$. 10257/2001), a edição de Plano Diretor pelo Município, e a edição de lei municipal específica para a área do imóvel assim tributado.
} 
da progressividade no tempo a que se refere o art. $182, \S 4^{o}$, inciso $I I, o$ imposto previsto no inciso I poderá: I - ser progressivo em razão do valor do imóvel" (grifo nosso).

A orientação adotada no acórdão, extensível a todos os tributos "reais", embora já ultrapassada por força da atuação do poder constituinte derivado, é importante para esta monografia por ser bastante representativa de uma postura da doutrina e da jurisprudência que procura conter a eficácia do princípio da capacidade contributiva, a despeito do discurso em favor de sua concretização. Na ementa, lê-se:

Sob o império da atual Constituição, não é admitida a progressividade fiscal do IPTU, quer com base exclusivamente no seu art. $145, \S 1^{\circ}$, porque esse imposto tem caráter real que é incompatível com a progressividade decorrente da capacidade econômica do contribuinte, quer com arrimo na conjugação desse dispositivo constitucional (genérico) com o art. $156, \S 1^{\circ}$ (específico) ${ }^{77}$.

O acórdão veio ao encontro da orientação de boa parte da doutrina:

Em regra geral, só os impostos pessoais se ajustam adequadamente à aplicação de critérios progressivos medidos pela capacidade contributiva, se bem que esta possa presumir da natureza, valor ou aplicação específica de determinada coisa, no sentido de que a possui, compra ou prefere o indivíduo de maiores recursos econômicos. Mas imposto sobre coisa, em princípio, exclui, por exemplo, a progressividade em atenção à pessoa, salvo casos de aplicação extrafiscal ${ }^{78}$.

A cobrança do IPTU por alíquotas progressivas diferenciadas em razão do valor ou do número de imóveis é fator de discriminação fiscal porque nada assegura que o proprietário de um ou vários bens de valor elevado tenha capacidade econômica superior à daquele que possui inúmeros imóveis de menor valor ${ }^{79}$

Na fundamentação, o Ministro Relator, Moreira Alves, entendeu que a cláusula constitucional da capacidade contributiva (Art. 145, $\S 1^{\circ}$ ) acolhia a distinção entre impostos "reais" e "pessoais"; classificação esta, aliás, questionável, como nos lembra, em lição contundente, Sacha Calmon:

É notável, no particular, como tratadistas de renome, tirantes os leguleios, continuam a proclamar que o IPTU é um imposto real, denunciando com isso: a) a má assimilação de lição da Ciência das Finanças; e b) insuficiente acuidade de análise jurídica, decorrente de repetição, sem espírito crítico, de avelhantadas afirmações.

\footnotetext{
77 STF. Recurso Extraordinário nº 153771-0/MG, Rel. Min. Moreira Alves, Brasília, 20 nov. $1996 . \quad$ Disponível em <http://www.stf.jus.br/portal/inteiroTeor/obterInteiroTeor.asp?id=211634\&idDocumento=\&codig oClasse $=437 \&$ numero $=153771 \&$ siglaRecurso $=\&$ classe $=R E>$. Acesso em 10/11/2009.

${ }_{78}^{78}$ BALEEIRO, Aliomar. Op. cit., p. 363.

${ }^{79}$ TORRES, Ricardo Lobo. Op. cit., p. 438.
} 
Sem embargo, estamos convencidos de que tal vezo enraíza-se, a par dos vícios acima expostos, em uma lembrança mal compreendida de certo tipo obrigacional que existia entre os romanos. Referimo-nos à obrigação ambulatória, em que a prestação era certus an e certus quando, mas o sujeito passivo tanto podia ser conhecido como não, por isso que a coisa ambulava com o dono, e este nem sempre era o mesmo (ambulant cum dominus). Este tipo de obrigação era comum em tributos que recaíam sobre bens imóveis, terras e edificações. Os romanos não se preocupavam com a coisa, por isso que a sua propriedade 'ambulava', em sentido legal, com seu dono, e este era exatamente quem devia pagar o tributo, fosse lá quem fosse. A muitos pareceu que a pessoa não tinha importância, mas a coisa, irrelevante o seu dominus, daí a idéia de um tributo real. Ora, dava-se exatamente o contrário. A pessoa do proprietário era o que importava, por isso que o tributo incidia sobre a condição jurídica ' ser proprietário': o imposto era pessoal. Real era o direito ${ }^{80}$ (grifo nosso).

Para o Ministro, a restrição à aplicabilidade do postulado da capacidade contributiva, e em particular de seu subprincípio da progressividade, justificava-se diante da redação da expressão "sempre que possível" no início do período. Essa interpretação, como vimos, não é autorizada pelo dispositivo constitucional, que não estabelece qualquer restrição ao alcance do princípio da capacidade contributiva. A expressão “sempre que possível”, não custa lembrar, é uma remissão ao necessário sopesamento, em face de tributos em concreto, em virtude de impossibilidades de ordem prática ou técnica, dos postulados da proporcionalidade, progressividade, personalização e seletividade. E não há qualquer óbice dessa ordem à incidência, no IPTU ou nos demais tributos sobre o patrimônio, da estrutura progressiva.

Com isso, relegou-se a capacidade contributiva, não obstante verdadeiro fundamento de qualquer tributação, a uma função secundária; sob a falsa alegação de que os impostos "reais" são instituídos com abstração deste princípio, por "impossibilidade”. Ao contrário: um sistema tributário será tão mais justo quanto mais conforme estiver ao princípio da capacidade contributiva, e isso inclui os tributos ditos "reais"; que não só podem como devem ter a estrutura progressiva e sua aplicação personalizada, em atenção às características pessoais do contribuinte. Como

\footnotetext{
${ }^{80}$ COELHO, Sacha Calmon N. Op. cit., p. 455.
} 
bem lembrou Sacha Calmon, mesmo o tributo dito "real" é pessoal, pois incide sobre a pessoa do contribuinte-proprietário.

A personalização dos tributos sobre o patrimônio é possível juridicamente e viável na prática. Relativamente ao IPTU, pode ocorrer quando, por exemplo, se adote o critério da quantidade de imóveis de propriedade do contribuinte. Um proprietário de único imóvel, que nele resida, pode ser desonerado - o próprio STF autoriza este tratamento ${ }^{81}$. Paradoxalmente, o mesmo tribunal, em linha com a proibição da progressividade, considera inconstitucional que se use o mesmo critério quantidade de imóveis - para majorar o IPTU ${ }^{82}$.

\subsubsection{Imposto de Transmissão de Bens Móveis e Imóveis por Causa Mortis ou Doação}

Não há autorização constitucional expressa para a progressividade desta espécie tributária; assim, mantido o entendimento do Supremo Tribunal Federal relativo à inconstitucionalidade da tributação progressiva de tributos "reais", salvo disposição expressa em contrário (como a que hoje existe quanto ao IPTU e ao ITR), é possível que uma tentativa de tributar-se progressivamente estas operações não se sustente diante de sua impugnação no Poder Judiciário.

O que é lamentável, pois, nesta espécie tributária, de competência dos Estados, ter-se-ia uma oportunidade para impor-se uma tributação mais acentuadamente progressiva, justamente em razão de seu caráter de transmissão gratuita:

É precisamente nas transmissões gratuitas, como naquelas a causa de morte ou por doação, que se surpreende o incremento da capacidade contributiva, apta a suportar a imposição atenta à justiça social e à igualdade. A efetivação do princípio pelas legislações estaduais contribuiria para se coarctar em parte a regressividade e a injustiça que imperam no sistema tributário brasileiro e o tornam odiosamente discriminatório ${ }^{83}$.

\footnotetext{
${ }^{81}$ STF. Súmula 539: "É constitucional a lei do município que reduz o IPTU imóvel ocupado pela residência do proprietário, que não possua qualquer outro".

${ }^{82}$ STF. Súmula 589: "É inconstitucional a fixação de adicional progressivo do imposto predial e territorial urbano em função do número de imóveis do contribuinte".

${ }^{83}$ TORRES, Ricardo Lobo. Op. cit., p. 447.
} 
O Senado Federal, no exercício da competência outorgada pela CF88 (Art. 155, §1 $\left.{ }^{\circ}, I V\right)$, editou a Resolução n. 09/1992, fixando a alíquota máxima instituível pelos Estados para o ITCMD em 8\%; limitando de forma considerável a viabilidade de uma estrutura mais acentuadamente progressiva.

Essa espécie tributária, como qualquer tributo sobre o patrimônio, presta-se à personalização; como se pode ler do texto:

Para que este tributo venha a contribuir com a distribuição da renda deveria ser progressivamente taxado na razão direta do valor do espólio, bem como do patrimônio do herdeiro. Assim, o quinhão de um herdeiro seria tanto mais taxado quanto maior fosse o valor da herança e também quanto maior fosse a renda de quem a recebesse ${ }^{84}$.

\subsubsection{Imposto Territorial Rural}

Hoje, formalmente, é progressivo; tendo a autorização constitucional sido implementada, também, por Emenda à Constituição, de nº. 42/2003, que alterou o Texto Maior para dispor o seguinte:

Art. 153. (...) $\S 4^{\circ}$. O imposto previsto no inciso VI do caput: I - será progressivo e terá suas alíquotas fixadas de forma a desestimular a manutenção de propriedades improdutivas; II - não incidirá sobre pequenas glebas rurais, definidas em lei, quando as explore o proprietário que não possua outro imóvel; III - será fiscalizado e cobrado pelos Municípios que assim optarem, na forma da lei, desde que não implique redução do imposto ou qualquer outra forma de renúncia fiscal.

Como avanço em relação ao texto originário, temos a adoção expressa da progressividade. Quanto a essa modalidade tributária, é importante notar a importância da progressividade de cunho extrafiscal, no âmbito da política fundiária, consoante a lição de Sacha Calmon ${ }^{85}$ :

\footnotetext{
Se a Constituição admite a expropriação (perda compulsória do direito de propriedade) mediante indenização em títulos da dívida agrária, para que cumpra a propriedade a sua função social que, no caso da propriedade agrária, é produzir e produzir bem no interesse da coletividade, é curial que o Estado pode elevar a tributação a níveis suficientemente insuportáveis de modo a estimular o proprietário rural a produzir adequadamente sob pena de, não o fazendo, ver-se obrigado a desfazer-se das terras, por ter-se tornado antieconômico mantê-las improdutivas ou insuficientemente produtivas. (...) O ITR progressivo, sem dúvida, é um poderoso instrumento de política fundiária, a ser utilizado com transparência, boa fé, firmeza e determinação. Andou bem o constituinte no particular. A progressividade só tem um limite: a alíquota maior não pode ser $100 \%$ (empatar com o valor fundiário). Será confiscarório.
}

\subsubsection{Imposto de Renda}

\footnotetext{
${ }^{84}$ HETZEL, Moacir. Op. cit., p. 111.

${ }^{85}$ COELHO, Sacha Calmon N. Op. cit., p. 348.
} 
O imposto sobre a Renda, por sua vez, apresenta uma progressividade "suave", tendendo, marginalmente, a um padrão regressivo em determinados casos.

As alíquotas que vigoram são incompatíveis com os valores dos pisos e tetos das faixas, implicando em um tratamento desigual a contribuintes dotados de capacidades econômicas radicalmente diferentes. Considerando a tabela em vigor para o ano-calendário de $2008^{86}$, antes, portanto, das mudanças promovidas em decorrência da crise econômica ${ }^{87}$, temos um limite de isenção no valor de $\mathrm{R} \$ 1.372,81$ mensais. Tal piso é muito baixo, se tomamos aquele patamar mínimo de subsistência necessário a uma família. Acima desse valor, incide sobre os rendimentos a alíquota de $15 \%$, até o patamar de $\mathrm{R} \$ 2.743,25$. Em seguida, a alíquota incidente é de $27,5 \%$, até o infinito. Esse nível mínimo rendimentos de $\mathrm{R} \$ 2.743,25$ para a alíquota máxima, $27,5 \%$, chega a ser um ultraje ao princípio da capacidade contributiva.

Ora, se a estrutura atual estivesse conforme o princípio, teríamos a seguinte situação: tomado, por hipótese, um acréscimo de $\mathrm{R} \$ 500$, concedido a dois contribuintes, com rendas atuais de $\mathrm{R} \$ 3$ mil e $\mathrm{R} \$ 50$ mil mensais, respectivamente; esse acréscimo equivaleria, no padrão de gastos de ambos, a um mesmo grau de essencialidade. Assim, o sacrifício que eles fariam ao dispor dessa quantia a mais seria idêntico - conclusão evidentemente absurda, considerando que o segundo contribuinte está muito além do chamado "mínimo existencial", enquanto o primeiro se encontra bem mais próximo deste nível.

Além desta crítica aos patamares das faixas de rendimentos, ocorre ainda que a progressividade "por faixas" atualmente em vigor impõe, dentro da mesma faixa, uma estrutura proporcional; isto é, adentrada uma

\footnotetext{
${ }^{86}$ Secretaria da Receita Federal. Imposto de renda pessoa física 2009: manual de preenchimento. Disponível

em <http://www.receita.gov.br/Publico/programas/irpf/2009/Orientacoes/Instrucoesmodelocompleto2 009.pdf $>$. Acesso em 10/11/2009, p. 43.

${ }^{87}$ Optamos por não considerar as alterações recentes, pois, embora tenham tornado a tabela mais justa, aumentando o número de faixas e seus respectivos patamares, constituem medidas anticíclicas conjunturais, que tendem a não se sustentar em tempos de normalidade.
} 
determinada faixa de renda, a alíquota incide de forma apenas proporcional dali em diante, sem aumentar progressivamente na medida em que aumenta a renda, como reza o postulado da progressividade. Esse fato não causaria grandes distorções não fosse a existência de apenas três faixas em nosso sistema; se compararmos, utilizando a tabela do anexo II, ao que seria adequado a uma estrutura progressiva, vemos que nos países mais avançados, e mesmos em países menos desenvolvidos como o nosso, há, em geral, mais faixas (o número de faixas médio, entre 27 países, foi calculado em 5), bem como as alíquotas superiores tendem a ser maiores que as vigentes no Brasil (a alíquota máxima apresentada entre os países foi calculada em $42,2 \%$, em média).

Temos, ainda, que o sistema de isenções e deduções vigente beneficia os mais ricos; e os regimes especiais de tributação, aplicáveis a determinadas fontes de renda: sobre rendimentos de aplicações financeiras, por exemplo, pode incidir uma alíquota de apenas $15 \%$, bem menor que a alíquota máxima ordinariamente aplicável, no valor de $27,5 \%$.

O Imposto sobre a Renda, tributo mais vocacionado à personalização, deveria ser o locus mais adequado à progressividade. A progressividade existente, porém, é muito branda, e penaliza os mais pobres. 


\section{Conclusão}

Nossa conclusão se baseia nas lições essenciais acerca do princípio da capacidade contributiva: a capacidade econômica que cada indivíduo expressa é, a um só tempo, o pressuposto para o ônus tributário e o critério de que o Estado deva se utilizar para graduar o quantum exigido. Mas também se apóia na diretriz distributiva prevista na Constituição, que manda o Estado promover a redução da desigualdade sócio-econômica; bem como no postulado da progressividade, que, ao exigir progressivamente mais tributos daqueles que detenham capacidades econômicas mais vultosas, confere maior concretude ao princípio da capacidade contributiva, superior à solução supostamente "neutra" do padrão de tributação proporcional, que, ao procurar manter a atual distribuição de riquezas, descumpre a diretriz distributivista da Constituição.

Importante, também observar, de lastro às nossas conclusões, que na política tributária, deve-se levar em consideração a possibilidade de que o contribuinte transfira o ônus tributário para um terceiro; também que a exigência tributária possa ser reduzida por meio de instrumentos os mais diversos como as deduções e isenções; atentando, enfim, para a soma global líquida efetiva exigida de cada indivíduo, abandonando uma perspectiva positivista-formalista, freqüente na doutrina jurídica e cega à complexidade da realidade. Sem considerar a interdisciplinaridade do fenômeno tributário, não se pode verificar a efetiva capacidade econômica tributável de cada indivíduo; obstando, portanto, a que se analise a conformação de um sistema tributário ao princípio da capacidade contributiva, tanto de uma forma geral, quanto para cada contribuinte em particular.

Tendo em consideração tais lições, no estudo do sistema tributário brasileiro, pudemos indagar sobre suas características, o que nos permitiu concluir acerca das razões que hoje concorrem para o fortalecimento do caráter regressivo geral do sistema. São elas, fundamentalmente, o peso 
muito elevado dos tributos tipicamente indiretos na arrecadação total (os "tributos sobre produtos"), o peso reduzido dos tributos diretos sobre a renda, a propriedade ou o capital na arrecadação, e, também, a predominância, na estrutura de incidência destes últimos, de um padrão proporcional (ocorrendo a progresssividade apenas de forma marginal e muito branda).

Não obstante o escopo bem restrito desta monografia (como convém a produções acadêmicas desta espécie), as conclusões a que chegamos podem servir de subsídio, afinal, para a formulação de um juízo de valor bastante negativo sobre o sistema tributário no Brasil. Isto porque, após estudarmos o conteúdo do princípio da capacidade contributiva, da progressividade, bem como suas implicações para a formulação de uma boa política tributária, e finalmente analisarmos o caso particular do sistema brasileiro, fica claramente evidenciado que este sistema não se acomoda aos ditames daquele princípio tão relevante. Em síntese, temos que o sistema tributário no Brasil, com sua estrutura de incidência regressiva, violenta o conteúdo mais elementar do princípio da capacidade contributiva.

Podemos ir além - o iníquo sistema tributário brasileiro não reconhece efetivamente a imunidade tributária das condições mínimas de existência digna do indivíduo. Ao onerar progressivamente mais os mais pobres, o sistema invade a seara da capacidade econômica não tributável, retirando dos indivíduos mais pobres além do que seria legítimo segundo o princípio da capacidade contributiva. Tal violação dos limites ao poder de tributar, elemento integrante do princípio, verifica-se mesmo quando levamos em consideração uma concepção bastante conservadora do direito ao "mínimo existencial" como a formulada por Ricardo Lobo Torres, e se torna ainda mais flagrante se tomamos por parâmetro a Constituição de 1988, uma vez que o conteúdo do que se considera direito ao "mínimo existencial", no Texto Maior, parece ter-se expandido.

Pode-se dizer que efetivar, no sistema tributário brasileiro, o princípio da capacidade contributiva, envolverá torná-lo verdadeiramente 
progressivo. Há, na doutrina e na jurisprudência, resistência contra esse movimento, como tivemos oportunidade de perceber; uma postura, enfim, de contenção da eficácia do princípio da capacidade contributiva, e, em especial, do postulado da progressividade. Um sistema tributário é tão mais justo e conforme a capacidade contributiva quanto mais tender à estrutura de incidência progressiva; a essa conclusão pudemos chegar após a crítica e a defesa deste postulado.

O princípio da capacidade contributiva, e seu refinamento da progressividade, envolvem, afinal, a implementação, no sistema tributário, do secular preceito segundo o qual se deva tratar desigualmente aos desiguais, na medida de sua desigualdade. Essa solução "geométrica" restaura o estatuto da igualdade em meio à brutal desigualdade da vida em sociedade; é, enfim, um remédio legítimo para tratar a disparidade entre as capacidades econômicas das pessoas.

Um sistema progressivo de tributação permite ao Estado influenciar a distribuição da riqueza na sociedade, conforme os objetivos socialmente desejados; possibilidade esta por tanto tempo ofuscada pelo brilho falso do mito da neutralidade do poder de $\operatorname{tributar}^{88}$. Parece-nos que, em cumprimento à diretriz constitucional distributivista, o postulado da progressividade tem grande potencial na construção de um país mais igualitário e justo.

\footnotetext{
${ }^{88}$ Essa crítica lê-se em HETZEL, Moacir. Op. cit., p. 106 e BERNI, Mauricio Batista. Op. cit. p.
} 65. 


\section{Bibliografia}

AFONSO, J.R.; ARAÚJO, E. A.A.; VIANNA, S.W. Carga tributária indireta no Brasil: Análise de incidência efetiva sobre as famílias. BID, Série de Estudos Econômicos e Sociais, 2004.

AMARO, Luciano. Direito tributário brasileiro, $14^{\mathrm{a}}$ ed. São Paulo: Saraiva, 2008 .

BALEEIRO, Aliomar. Limitações ao poder de tributar, $5^{\mathrm{a}}$ ed., ver. de acordo com a Emenda Constitucional n. ${ }^{\circ}$ 1, de 1969, e com o C.T.N. Rio de Janeiro: Forense, 1977.

BERNI, Mauricio Batista. A capacidade contributiva e a concentração de rendas. Rio de Janeiro. 1982. Dissertação (mestrado). Departamento de Ciências Jurídicas da PUC-Rio.

COELHO, Sacha Calmon Navarro. Comentários à constituição de 1988: sistema tributário, $8^{a}$ ed. Rio de Janeiro: Forense, 1999.

HETZEL, Moacir. Possibilidades e limites do direito tributário num processo de distribuição de renda, 1993. Dissertação (Mestrado) Departamento de Ciências Jurídicas da PUC-Rio.

INSTITUTO DE PESQUISA ECONÔMICA APLICADA. Cláudio H. dos Santos et. al. A evolução da Carga Tributária Bruta Brasileira no período 1995-2007: tamanho, composição e especificações econométricas agregadas (texto para discussão). Brasília, 2008. Disponível em http://www.ipea.gov.br/sites/000/2/pdf/CT_3_4_2008_TD_Final.pdf>. Acesso em 10/11/2009. 
INSTITUTO DE PESQUISA ECONÔMICA APLICADA. Comunicado da $\begin{array}{llll}\text { Presidência } & n^{o} \text {. } 22 . & \text { Disponível em }\end{array}$ <http://www.ipea.gov.br/sites/000/2/comunicado_presidencia/09_06_30_C omunicaPresi_22_ReceitaPublica.pdf>. Acesso em 20.09.2009.

INSTITUTO DE PESQUISA ECONÔMICA APLICADA. Justiça Tributária. $\quad$ Brasília, $2008 . \quad$ Disponível em <http://www.ipea.gov.br/sites/000/2/pdf/08_06_05_JusticaTributaria.ppt >. Acesso em 28.09.2009.

MACHADO, Orvácio Lyra. A concentração da renda e o sistema tributário nacional. Rio de Janeiro. 1979. Dissertação (Mestrado) - Departamento de Ciências Jurídicas da PUC-Rio.

MELLO, Celso Antônio Bandeira de. O conteúdo jurídico do princípio da igualdade. São Paulo: Revista dos Tribunais.

MELLO, Celso Antônio de. Curso de direito administrativo, $23^{\mathrm{a}}$ ed. São Paulo: Malheiros, 2007.

OLIVEIRA, José Marcos Domingues de. Direito tributário: Capacidade contributiva: conteúdo e eficácia do princípio. Rio de Janeiro: Renovar, $198 B 8$.

OLIVEIRA, José Marcos Domingues de. Direito tributário: Capacidade contributiva: conteúdo e eficácia do princípio, $2^{\mathrm{a}}$ ed. Rio de Janeiro: Renovar, 1998.

PIRES, Adilson Rodrigues; TÔREES, Heleno Taveira Pires e Heleno Taveira Tôrres (org.), Princípios de direito financeiro e tributário - estudos 
em homenagem ao professor Ricardo Lobo Torres. Rio de Janeiro: Renovar, 2006.

SECRETARIA DA RECEITA FEDERAL. Estudo Tributário $N^{o}$ 04: A Progressividade no Consumo Tributação Cumulativa e sobre o Valor Agregado. Brasília, 2002. Disponível em $<$ http://www.receita.gov.br/Publico/estudotributarios/estatisticas/16\%20Pro gressividade\%20no\%20Consumo.pdf>. Acesso em 10/11/2009.

SECRETARIA DA RECEITA FEDERAL. Imposto de renda pessoa física 2009: manual de preenchimento. Disponível em $<$ http://www.receita.gov.br/Publico/programas/irpf/2009/Orientacoes/Instru coesmodelocompleto2009.pdf>. Acesso em 10/11/2009.

SILVA, José Afonso da. Curso de direito constitucional positivo, $26^{\mathrm{a}} \mathrm{ed}$. São Paulo: Malheiros.

SMITH, Adam, Investigação sobre a natureza e as causas da riqueza das nações. Tradução de Luiz João Baraúna, $3^{a}$ ed., vol. III (coleção os economistas). São Paulo: Nova Cultural, 1988.

STF. Recurso Extraordinário nº. 153771-0/MG, Rel. Min. Moreira Alves, Brasília, 20 nov. $1996 . \quad$ Disponível em $<$ http://www.stf.jus.br/portal/inteiroTeor/obterInteiroTeor.asp?id=211634\& idDocumento $=\&$ codigoClasse $=437 \&$ numero $=153771 \&$ siglaRecurso $=\&$ clas $\mathrm{se}=\mathrm{RE}>$. Acesso em 10/11/2009.

TORRES, Ricardo Lobo. Curso de direito financeiro e tributário, $12^{\mathrm{a}}$ ed. Rio de Janeiro: Renovar, 2005. 
TORRES, Ricardo Lobo. Tratado de direito constitucional financeiro e tributário, v. III: os direitos humanos e a tributação: imunidades e isonomia. Rio de Janeiro: Renovar, 1999. 


\section{Anexo ${ }^{89}$}

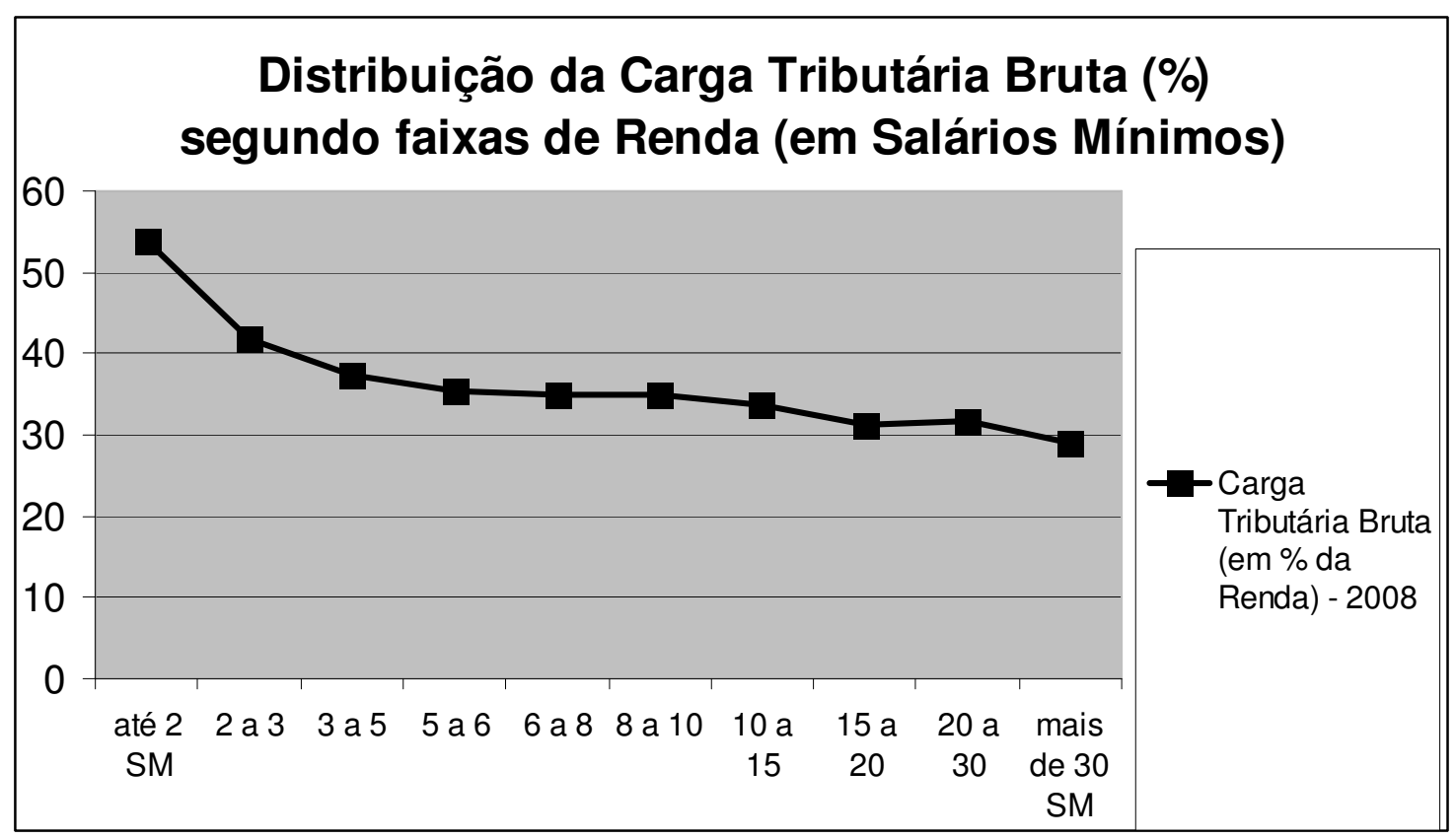

${ }^{89}$ Gráfico elaborado a partir do tabela 01 de Instituto de Pesquisa Econômica Aplicada (IPEA). Comunicado da Presidência $n^{o}$ 22. $\quad$ Disponível em <http://www.ipea.gov.br/sites/000/2/comunicado_presidencia/09_06_30_ComunicaPresi_22_Rece itaPublica.pdf>. Acesso em 20.09.2009, tabela 1. 
Anexo II $^{90}$

\section{IRPF de países selecionados}

\begin{tabular}{|c|c|c|c|}
\hline \multirow[b]{2}{*}{ País } & \multicolumn{3}{|c|}{ Alíquotas (\%) } \\
\hline & Faixas & Mínima & Máxima \\
\hline Alemanha & 3 & 22,9 & 53,0 \\
\hline Argentina & 7 & 9,0 & 35,0 \\
\hline Austrália & 4 & 7,0 & 47,0 \\
\hline Áustria & 5 & 2,0 & 50,0 \\
\hline Azerbaijão & 6 & 12,0 & 35,0 \\
\hline Barbados & 2 & 25,0 & 40,0 \\
\hline Bélgica & 7 & 5,0 & 55,0 \\
\hline Bolívia & 5 & 15,0 & 30,0 \\
\hline Brasil & 2 & 15,0 & 27,5 \\
\hline Bulgária & 4 & 16,0 & 38,0 \\
\hline Canadá & 4 & 5,0 & 29,0 \\
\hline Chile & 6 & 5,0 & 45,0 \\
\hline China & 9 & 15,0 & 45,0 \\
\hline Espanha & 6 & 15,0 & 39,6 \\
\hline Estados Unidos & 5 & 15,0 & 39,6 \\
\hline França & 12 & $5, \mathrm{O}$ & 57,0 \\
\hline Grécia & 5 & 5,0 & 42,5 \\
\hline Holanda & 4 & 6,2 & 60,0 \\
\hline Israel & 5 & 10,0 & 50,0 \\
\hline Itália & 5 & 18,0 & 45,0 \\
\hline Japão & 4 & 10,0 & 37,0 \\
\hline Nova Zelândia & 3 & 19,5 & 39,0 \\
\hline Peru & 2 & 15,0 & 20,0 \\
\hline Portugal & 6 & 12,0 & 40,0 \\
\hline Reino Unido & 3 & 20,0 & 40,0 \\
\hline Suíça & 3 & 31,0 & 57,0 \\
\hline Média Aritmética & 5 & 12,9 & 42,2 \\
\hline
\end{tabular}

\footnotetext{
${ }^{90}$ Instituto de Pesquisa Econômica Aplicada (IPEA). Justiça Tributária. Brasília, 2008. Disponível em <http://www.ipea.gov.br/sites/000/2/pdf/08_06_05_JusticaTributaria.ppt $>$. Acesso em 28.09.2009, Slide $\mathrm{n}^{\circ} .33$.
} 